\title{
Pro-Environmental Households
} and Energy Efficiency in Spain

Ana Ramos

Xavier Labandeira

Andreas Löschel 


\title{
Pro-Environmental Households and Energy Efficiency in Spain
}

\author{
Ana Ramos*, Xavier Labandeira and Andreas Löschel
}

\begin{abstract}
The residential building sector is a major driver of current and future energy consumption and associated emissions, which can be potentially mitigated through significant energy-efficiency (EE) improvements in both emerging and developed countries. Yet, there are several persistent barriers that hinder the attainment of EE improvements in this area. Using data from a 2008 national representative survey of Spanish households, this paper is interested in the determinants of EErelated decisions. In particular, a discrete-choice model empirically analyzes whether pro-environmental households are more likely to invest in EE and to adopt daily energy-saving habits. We show that households with eco-friendly behaviors are more likely to investment in well-differentiated EE measures as well as to steer daily habits towards energy savings. However, no effects are found for households with environmental attitudes based on stated willingness to pay to protect the environment. In addition to this, households belonging to higher income groups and education levels are more likely to invest in EE but not to adopt energy-saving habits; while households with older members are less likely to invest in EE and show fewer eco-friendly habits.
\end{abstract}

Keywords: Energy efficiency, investment, behavior, habits

JEL Classification: Q41, Q48, Q58

Ramos is at Rede, University of Vigo, Spain. Labandeira is at Rede and FSR-Climate (European University Institute), Italy. Löschel is at the Westfälische Wilhelms-University Münster and at the Centre for European Economic Research (ZEW), Germany.

* Corresponding author: Facultade de CC. Económicas, Universidade de Vigo, Campus As Lagoas, 36310 Vigo, Spain. Email: anaramos@uvigo.es

The authors are grateful to the Spanish Ministry of Science and Innovation project ECO2009-14586-C2-01 and to the Fenosa chair at the University of Vigo for funding this research. They are also thankful to Mohcine Bakhat, Alberto Gago, Matthew Kotchen, José M. Labeaga, Pedro Linares, Xiral López, María L. Loureiro, Alicia Pérez and Kathrine von Graevenitz for their helpful comments and suggestions. Yet the paper only reflects the views of the authors, who are responsible for any error or omission that may remain. 


\section{Introduction}

Buildings have become a centerpiece for energy and environmental policies due to their large impacts on energy demand and related emissions. Indeed, residential and commercial buildings account for approximately $40 \%$ of final energy consumption in industrialized countries. Unlike other sectors, the stock or inertia effect of buildings is of particular concern given that many units were built under old (or without) codes and thus often without significant attention to energy efficiency or environmental issues. Buildings are long-term durable goods; hence, their contributions to future energy consumption and emissions are likely to be large unless specific actions and policies are introduced (Gago et al., 2013).

Energy efficiency (EE) offers an opportunity to change this trend by applying cost-effective measures to reduce energy consumption (Levine et al., 2007). In the last few years international institutions such as the International Energy Agency (IEA) have emphasized the potential energy savings achievable from building design and retrofitting, and have urged governments to introduce policies to promote EE in this sector (IEA, 2013) such as codes and standards, taxes and subsidies and other non-price instruments (see Markandya et al., 2015). Some of these measures consist of improving the technical conditions of buildings so that they need less energy to provide the same service, e.g. through insulation, more efficient heating systems or the use of highly energy-efficient appliances Moreover, consumers can reduce their daily energy consumption by adopting energy-saving habits such as switching off lights or targeting lower (upper) interior temperatures in winter (summer).

Yet widespread EE adoption has hardly been observed in this sector given strong factors that prevent agents from taking advantage of EE potentials (see e.g. Levine et al., 2007, European Commission, 2011). Some of the most important barriers are informational imperfections and behavioral failures, as this is a complex sector with a multitude of agents and high costs, along with limited access to capital (Jaffe and Stavins, 1994). Yet these effects might be less pronounced for households that show environmental concerns, even in the case of incomplete information, principal-agent problems, bounded rationality or long payback periods. Proenvironmental households might value not only the monetary savings derived from reducing their energy use, but also the environmental improvement associated with energy savings; hence they may favor EE more than the rest of the households. This could lead, for instance, to a more exhaustive search for information when buying new appliances, to shorter payback periods, or to more attention to energy performance attributes (given by energy performance certificates or labeling systems). In the same way, if the members of a household are concerned with environmental protection they might (contrary to principal-agent hypothesis) save energy at home by adopting eco-friendly habits, such as turning down the heating thermostat even if they do not pay the bill directly (IEA 2007). Finally, pro-environmental households might be less prone to traditional or cultural aspects as well as behavioral failures that prevent consumers from taking optimal decisions.

This paper attempts to empirically determine the factors that drive Spanish household decisions in EE investments and the adoption of daily energy-saving habits, using the Spanish National Statistics Institute (INE) 2008 survey, 'Encuesta Social: Hogares y Medio Ambiente' (ESHMA, Social Survey: Households and the Environment), a single-year representative survey containing micro data on Spanish households. Similar analyses previously performed for other developed countries have mostly considered dwelling structural and socio-economic variables. However, the importance of environmental issues in understanding household decision-making processes with respect to $E E$ and energy consumption has been recently emphasized by 
different authors (e.g. Loureiro et al., 2013; Vassileva et al., 2012; Ek and Söderholm, 2010), as well as the need for further empirical evidence regarding these hypotheses (Van den Bergh, 2008).

Our study provides new evidence on the role of environmental issues for EE adoption in a well-differentiated set of measures determined by their monetary costs, from costless measures, such as the adoption of daily energy-saving habits, to low and high-cost investments, such as the acquisition of low consumption bulbs, major EE appliances (those with A or A+ label), and double glazing. Additionally, we include questions related to both environmentally-friendly attitudes and behaviors. Previous findings (Lange et al., 2014) showed that questions related to current behavior are expected to be better indicators of future actions than questions based on attitudes, as indicated by psychologists (Kollmuss and Agyeman, 2002). In the environmental valuation literature it is well-known that social pressure can lead respondents to report socially acceptable answers that might bias the effect of stated preferences (Green and Tunstall, 1999; Kollmuss and Agyeman, 2002). We found that environmentally-friendly behaviors have positive effects on EE investments and steer habits towards energy savings, contrary to responses related to environmental attitudes. Moreover, we found that environmentally-friendly behaviors are less important in high-cost investments. This result might suggest the existence of a trade-off between household environmental concerns and monetary costs. Additionally, high-cost investments can suffer from principal/agent problems, financial constraints or low replacement rates that could prevent consumers to act according to their environmental concerns. Besides, households belonging to higher income groups were found to be more likely to invest in $E E$, but less likely to adjust daily energy-saving habits, while households with older members were less likely to invest in EE and showed less eco-friendly EE habits.

Although the results of this paper are obviously of particular relevance for Spain, they may also be useful for countries and regions that share some of its characteristics. For instance, over $50 \%$ of existing buildings in Spain were constructed before 1980, a time when building codes had no EE requirements. Moreover, between 1998-2008 Spain saw a construction boom that considerably expanded the stock of residential buildings and created a significant inertia that calls for a detailed analysis of EE options and responses in this sector. However, both in Spain and elsewhere, policy-makers should have a deep understanding about the factors driving EE-related decisions before designing and/or implementing corrective strategies in different sectors and/or specific groups.

The paper is organized in five sections and two annexes (summary statistics and estimation results), including this introduction. Section 2 reviews the existing literature in the field, whereas Section 3 describes the source of data used in our analysis and the main variables. Section 4 presents the results of the empirical model and discusses some implications. Finally, Section 5 deals with the main conclusions.

\section{Literature}

Constraints and barriers to a successful adoption of EE in residential buildings explain the proliferation of public policies encouraging EE over the last years, particularly intensive in the EU, with the introduction of several EE instruments and packages such as codes and standards, labeling systems, information programs, subsidies or taxes, etc. (see e.g. Gillingham et al., 2006, 2009; Levine et al., 2007; Linares and Labandeira, 2010; Ryan et al., 2011, Gago et al., 2013). However, these policies are unlikely to be successful unless they 
are designed with good knowledge of the residential market. That is why several empirical studies have attempted to identify not only the socio-economic characteristics that determine household adoption of EE but also other features and constraints that prevent the implementation of cost-effective EE measures.

In this context, most academic research has focused on principal-agent problems in both EE investment and energy-saving habits. One of the first contributions in this area was Brechling and Smith (1994) who used micro-data from the 1986 'English House Condition Survey' to explain the probability to have wall and loft insulation and double glazing in UK households. The paper showed small income-related effects suggesting no barriers to capital access, whereas home ownership was the only socio-economic characteristic that influenced EE investment decisions. Levinson and Niemann (2004) used US data from the 'Residential Energy Consumption Survey' (RECS) and the 'American Housing Survey' to analyze principal-agent problems in household winter indoor temperatures. Comparing results from OLS and selection probit models, they showed negative EE effects of contracts which included energy costs in rental payments. Davis (2012) employed data from the 2005 RECS and a linear probability model to study the importance of principal-agent problems in EE appliances and lighting and demonstrated the effectiveness of command-and-control approaches. Maruejols and Young (2011) used data from the 2003 Canadian 'Survey of Household Energy Use' to study energyrelated behavior in multi-family dwellings. Their results indicate that households not paying heating bills directly chose higher temperature settings. While income effects were small for temperatures, income was an important determinant of household eco-friendly habits. Gillingham et al. (2012) employed the 2003 'California Statewide Residential Appliance Saturation Study' to find the effects of certain variables on morning heating temperatures, changes of heating system or insulation level. Using probit models they identified principalagent problems both in heating or cooling and insulation. They attributed lower heating temperatures in colder regions and larger houses to economic incentives from more substantial energy-saving opportunities. Finally, Miller et al., 2014 estimate the likelihood of adoption of energy efficiency measures in the residential sector in the US, with the focus on the principal-agent problem. To do so, they also used data from the RECS 2009 and an energy efficiency index constructed by their own which contains information about the updated appliances, windows replacement, added insulation, and the use of programmable thermostat among others. Their results show that households from urban areas, married, belonging to high income class or high educational levels are more likely to adopt energy efficiency measures. They also found that rental units with heat-inclusive rents are less likely to adopt energy efficiency measures, confirming the existence of split incentives.

Although environmental concerns could be a crucial determinant in the decision-making processes of households and could explain differences in the level of energy consumption of households with similar characteristics (Vassileva et al., 2012; Ek and Söderholm, 2010), none of the above-mentioned papers included such variables. Indeed, Van den Bergh (2008) stressed the small number of empirical studies that combine socio-economic and psychological determinants of environmentally-friendly behavior. As of yet only a few papers have introduced different variables to measure possible effects on general energy-related decisions, such as Kahn (2007), who studied the relationship between a green political ideology and private consumer choices, or Kotchen and Moore (2007) who use household environmental attitudes as one of the explanatory variables which determine the participation in green-electricity programs. 
Table 1. Environmental Questions in EE Studies on Buildings

\begin{tabular}{|c|c|}
\hline Paper & Environmental attitude variable \\
\hline Di Maria et al. (2008) & $\begin{array}{l}\text {-Respondent's support of the Kyoto Protocol } \\
\text {-Importance given to the protection of the environment } \\
\text {-Whether the respondent has heard of global warming and the greenhouse } \\
\text { effect }\end{array}$ \\
\hline Kahn and Vaughn (2009) & $\begin{array}{l}\text {-Neighborhood's Green Party's share of registered voters } \\
\text {-Share of voters who voted in favor of Proposition } 12 \text { on March 7, } 2000 . \\
\text {-Share of voters who voted in favor of Proposition } 13 \text { in the year } 2000 .\end{array}$ \\
\hline Costa and Kahn (2010) & $\begin{array}{l}\text {-Whether the household has donated money to environmental groups } \\
\text {-Whether the household has signed up for the renewable energy program } \\
\text { of the utility }\end{array}$ \\
\hline Lange et al. (2014) & $\begin{array}{l}\text {-Whether the respondents believe that their country will be affected by } \\
\text { climate change in the future } \\
\text {-If households consider that their actions are influenced by carbon dioxide } \\
\text { emissions } \\
\text {-If the respondents agreed with the statement that the environment was a } \\
\text { low priority compared to many other things in their lives. } \\
\text {-Whether the respondent believes that it takes too much time and effort to } \\
\text { do things that are environmentally friendly } \\
\text {-If respondents are environmentally friendly in most things they do } \\
\text {-How often the respondents dress warmer when they feel cold rather than } \\
\text { turning the heating on or turning it up }\end{array}$ \\
\hline Brounen et al. (2012) & -Efficient drivers \\
\hline OECD (2013) & $\begin{array}{l}\text {-Green Growthers } \\
\text {-Altruist } \\
\text {-Skeptics } \\
\text {-NGO } \\
\text {-Environmental NGO } \\
\text {-Environment as top concern } \\
\text {-Economy as the top concern } \\
\text {-Understand Climate Change } \\
\text {-Cost bias }\end{array}$ \\
\hline
\end{tabular}

Source: the authors

Studies on the effects of pro-environmental households on EE decisions have focused on different areas showing mixed evidence. This fact could be partially due to the way environmental concerns are measured. Table 1 displays the specific questions different studies have used to estimate the effect of environmental concerns on EE investment and energy-saving habits. Di Maria et al. (2008) used 2001 data from a representative survey of Irish households to find positive effects of environmental attitudes (measured as indicated in the table) on the adoption decision of compact fluorescent light bulbs. They also identified education as the most important determining factor, with income and rural being important as well. However, variables associated with the household's life-cycle (age, gender, marital status and number of dependent children) were not found to be statistically significant. Similarly, Costa and Kahn (2010) included information on donations and support for environmental protection to estimate the effect on California's residential electricity consumption. They suggested that green voters and those enrolled in the renewable energy program of their utility used less energy. In a subsequent paper, Kahn and Vaughn (2009) showed that the share of green 
voters explained the aggregate share of hybrid cars and LEED' certified buildings in communities. Lange et al. (2014) employed a cross section of the 'British Household Panel Survey' to test the 'green hypocrisy' hypothesis on the UK. They tested the effect of environmental attitudes, beliefs and behaviors on residential space heating expenditures with an OLS model, showing that environmental attitudes do not necessarily lead to lower heating expenditures. Their results point out that indeed only those households that actively put their beliefs into practice in daily life had lower heating expenditures. With respect to income, they found a positive and statistical relationship with heating temperature, while the effect of education depended on the chosen model specification. Brounen et al. (2013) used data from the 2011 'Dutch National Bank Household Survey', and found that consumer attitudes towards energy conservation and demographics had a direct effect on the heating and cooling behavior of residential households, while energy literacy (i.e. whether households are able to make EE trade-offs) and awareness of their energy consumption had no effect. Households that declared to have driven efficiently to save petrol were more likely to know their energy bills and use green power, although this did not have any effect on indoor heating temperature. Additionally, they found no effect in green party voters. Finally, the OECD Survey on Household Environmental Behavior and Attitudes carried out in 2011 across 11 OECD countries, including Spain, introduced 7 questions connected to household environmental attitudes such as participating in a NGO or considering the environment as the most pressing concern (OECD, 2013). In a recent paper, Ameli and Brandt (2014) found that on average some of the cited variables increase the likelihood of energy efficient investment adoption.

\section{Data}

This paper uses micro-data from the INE's ESHMA, a single-year representative survey with almost 27,000 household principal dwellings that was carried out between April and December 2008 through internet, telephone and face-to-face interviews. The survey intended to gather comprehensive information on Spanish household consumption and environmental habits (energy conservation, water saving, recycling, etc.), even though data do not allow any dynamic analysis. The survey consists of nine blocks: i) information about household characteristics (income, education, number of members, etc.); ii) water supply and adoption of water saving measures; iii) energy sources of the house and installed heating, air conditioning and lighting systems (type of energy they use, type of heating fuel, thermostat temperature settings chosen by the members, proportion of rooms with air conditioning, low-consumption bulbs, etc.); iv) recycling practices; v) equipment and appliances; vi) noises and bad smells; vii) transport (number and type of vehicles); viii) general issues on lifestyle and consumption and ix) specific questions for the respondent.

The strength of this database is the vast number of questions related to household environmental attitudes and habits. This allows us to study the extent to which households reporting to be environmentally concerned or showing eco-friendly practices are more likely to invest in EE in their dwellings and the extent to which their environmental attitudes and behaviors are translated into daily energy-saving habits.

Using the questions related to household environmental concerns in the ESHMA, proxies of environmental attitudes and behavior can be defined. Green and Tunstall (1999) indicate that reports regarding hypothetical situations do not coincide with those in which the situations are real. This statement falls in line with the results reported by Lange et al. (2014), who found that environmental attitudes and environmental behaviors yield to

\footnotetext{
${ }^{1}$ This is a certification system for high-energy efficiency products from the U.S. Green Building Council.
} 
different results. We thus create two dummy variables to measure environmental attitudes, 'RENEWABLE' and 'TAX', which take value one when respondents answer yes and zero otherwise, respectively, to the following survey questions: i) Are you willing to pay more to use renewable energies?; ii) Would you agree on establishing a new environmental tax on the most pollutant fuels? Both questions report stated willingness to pay (WTP) to protect the environment.

Regarding environmental behavior, we create two indexes that measure the degree of household environmental activities. As in Knack and Keefer (1997) or Owen and Videras (2006) we first construct an index that measures household environmental policy activism. This 'ACTIVISM' index takes values from 0 to 5 , by adding 1 each time the individual has answered "yes" to the following five questions: i) collaborated with any environmental protection organization, ii) participated in any voluntary work to protect the environment, iii) signed a petition related with environmental protection, iv) attended any demonstration in defense of environment, and v) reported some environmental problem individually identified. Following the same methodology, we construct a second index, 'RECYCLING', that measures the number of types of products the household recycles. The variable 'RECYCLING' goes from 0 , if the household does not recycle, to 4 if the household recycles organic, paper, glass and plastic and can waste.

Finally we use a well-differentiated set of proxies that allows us to check the robustness of our results. The two attitudinal variables are based on a single question with only two possible answers (yes/no), while behavioral variables are based on indexes. As Torgler and García-Valiñas (2007) noted, indexes allow us to use more complete information by considering middle positions, while single questions avoid problems associated to the construction of indexes.

To estimate the effects of household characteristics on EE decisions we use the standard socio-economic variables: income, employment situation of the main preceptor (unemployed, employed, retired), educational level, number of members (\#members), children (\#members<16) and elderly (\#members>65) and nationality. Based on economic rationality and previous findings, we can formulate different hypotheses: We expect $E E$ products and services to be normal goods and hence, expect the income to have a positive effect on the probability to invest in EE and to set higher heating temperatures. The effect of employment is expected to be similar to the effect of income. Education is expected to have a positive effect on investment, although how it affects habits is unclear. Di Maria et al. (2008) argue that respondents with a higher level of education might be better able to predict future operational costs. The number of members, the number of children under 12 years and the number of elderly might reflect the life-cycle effect. A household with children might have a more intensive use of electric equipment and thus could be more interested in purchasing EE products. On the contrary, elderly households are expected to be less likely to purchase EE investments since the return period will be shorter. At the same time, both children and elderly might have higher comfort necessities, so we expect a positive effect on the probability to set higher temperatures.

Additionally, we include some control variables for geographic localization: a variable that classifies municipalities by size (municipality size); dummies for climatic zones², and a dummy for each Autonomous

2 For the climatic zones, we follow the specification used by IDAE (Spanish Institute for Diversification and Energy Saving) in the SECH-SPAHOUSEC project (IDAE, 2011). This classifies the country into 3 areas based on maximum, medium and minimum average temperatures along the period 1997-2007. Hence the variable takes values equal to one for North Atlantic, two for Continental and three for Mediterranean areas. 
Community (administrative region). The size of the municipality is important since it can determine the degree of access to certain devices or information, whereas Autonomous Community dummies control for different subsidy programs that regional governments have voluntarily implemented in order to promote $\mathrm{EE}$ (for example, the Renove programs for the substitution of all appliances or the installation of double glazing). These dummies collect the divergence in the magnitude, the time of implementation and other important characteristics of these subsidies. Galarraga et al. (2011a) and (2011b) found that these subsidies have increased the share of appliances with label A+. However, according to the IDAE (Spanish Institute for Diversification and Energy Saving) only $23 \%$ of households have received subsidies for appliances, $4 \%$ for heating systems and 3\% for insulation (IDAE, 2011). Table 2 summarizes the statistics of these main variables, while the others are fully depicted in the two annexes of the paper.

Table 2. Summary Statistics of the Main Variables

\begin{tabular}{|c|c|c|c|}
\hline Variable & Measurement & $\begin{array}{l}\text { Total } \\
\text { Obs. }\end{array}$ & Mean $/ \%$ \\
\hline Nationality & Dummy & 26034 & 0.94 \\
\hline $\begin{array}{l}\text { Professional } \\
\text { situation }\end{array}$ & $\begin{array}{l}\text { Employed (reference) } \\
\text { Unemployed } \\
\text { Retired }\end{array}$ & 26034 & $\begin{array}{l}52.39 \% \\
16.80 \% \\
30.81 \%\end{array}$ \\
\hline $\begin{array}{l}\text { Educational } \\
\text { level }\end{array}$ & $\begin{array}{l}\text { Basic (reference) } \\
\text { Primary school } \\
\text { Secondary school } 1 \text { st stage } \\
\text { Secondary school } 2^{\text {nd }} \text { stage } \\
\text { Vocational school } \\
\text { University }\end{array}$ & 26030 & $\begin{array}{l}15.71 \% \\
32.01 \% \\
12.11 \% \\
12.68 \% \\
12.18 \% \\
15.30 \% \\
\end{array}$ \\
\hline \#members & Number & 26034 & 2.67 \\
\hline \#members $<16$ & Number & 26034 & 0.38 \\
\hline \#members $>65$ & Number & 26034 & 0.47 \\
\hline Income & $\begin{array}{l}<1.100 € / \text { month(reference) } \\
1.101-1.800 € / \text { month } \\
1.801-2.700 € / \text { month } \\
>2.700 € / \text { month }\end{array}$ & 20530 & $\begin{array}{r}26.64 \% \\
27.43 \% \\
15.38 \% \\
9.41 \% \\
\end{array}$ \\
\hline $\begin{array}{l}\text { Municipality } \\
\text { size }\end{array}$ & $\begin{array}{l}<10.000 \text { inhab.(reference) } \\
10.000-20.000 \text { inhab. } \\
20.000-50.000 \text { inhab. } \\
50.000-100.000 \text { inhab. } \\
>100.000 \text { inhab. }\end{array}$ & 26034 & $\begin{array}{r}25.24 \% \\
12.32 \% \\
15.61 \% \\
8.34 \% \\
38.50 \% \\
\end{array}$ \\
\hline Climatic zone & $\begin{array}{l}\text { North Atlantic (reference) } \\
\text { Continental } \\
\text { Mediterranean }\end{array}$ & 24423 & $\begin{array}{l}27.54 \% \\
18.81 \% \\
47.45 \% \\
\end{array}$ \\
\hline ACTIVISM & Index & 23979 & 0.29 \\
\hline RECYCLING & Index & 26034 & 2.85 \\
\hline RENEWABLE & Dummy & 23977 & 0.23 \\
\hline TAX & Dummy & 23979 & 0.63 \\
\hline
\end{tabular}


It is important, however, to note that the ESHMA also has important weaknesses. First of all, there is no information on structure, age or size of dwellings. Research in the field has usually found these factors to be relevant in explaining the likelihood of adoption of EE measures (e.g. Brechling and Smith, 1994), so this absence should be taken into account when interpreting the results of this paper. In addition, the survey lacks two other important variables: energy consumption and ownership status. The former is unlikely to be available in large national surveys since, as of yet, there are no official databases combining information on both energy consumption and EE decisions. This gap, which has only been covered for household heating expenditures, makes it impossible to gain insights on the potentially reciprocal effects between energy consumption and the decision to invest or adopt EE measures. Regarding ownership status, this dataset does not allow for the analysis of the principal-agent effect, another important factor explaining $E E$ investment and energy consumption (see Section 2). Nevertheless, in Spain the magnitude of the principal-agent effect may not be as important as it is in other countries due to the high rate of owner-occupied dwellings ( $82 \%$ in 2008 ).

\section{Models and results}

Following the usual distinction between EE investment decisions and daily energy-saving habits in the literature (see Sections 1 and 2), we also deal with these issues individually in our empirical application. To study the determinants of EE investments we employ the ESHMA questions regarding high EE labels for major appliances, the use of low consumption bulbs, and the existence of double glazing. Regarding the determinants of EE consumption habits we use the heating temperature chosen by households for daytime consumption.

\subsection{EE investment}

To validate results, we study EE investments across well-differentiated sections of the house. We present a baseline regression model that will be used to estimate the effect of socio-economic and environmental factors on the probability of having invested on each one of the preceding measures (A or A+ fridge, washing machine, dishwasher, oven, double glazing and low consumption bulbs), being high rated appliances the first model specification. This selection is based on the fact that appliances and equipment represent the third largest portion of household energy consumption in industrialized countries (Laustsen, 2008; Levine et al., 2007; European Commission, 2011). Figure 1 shows the residential breakdown of energy consumption for Spain and the EU in 2010. It explains why the substitution of major energy-inefficient appliances has been the target of many public EE policies. In particular, our survey asks respondents whether their fridge, washing machine, dishwasher and oven have an A or A+ label. We follow Gillingham et al. (2012) and restrict the sample to households that have bought their major appliances over the last five years. Therefore, we exclude situations where labels had not been implemented yet, and also reduce possible effects of changing trends on the supply side. 
Figure 1. Spanish and EU Residential Energy Breakdown in 2010

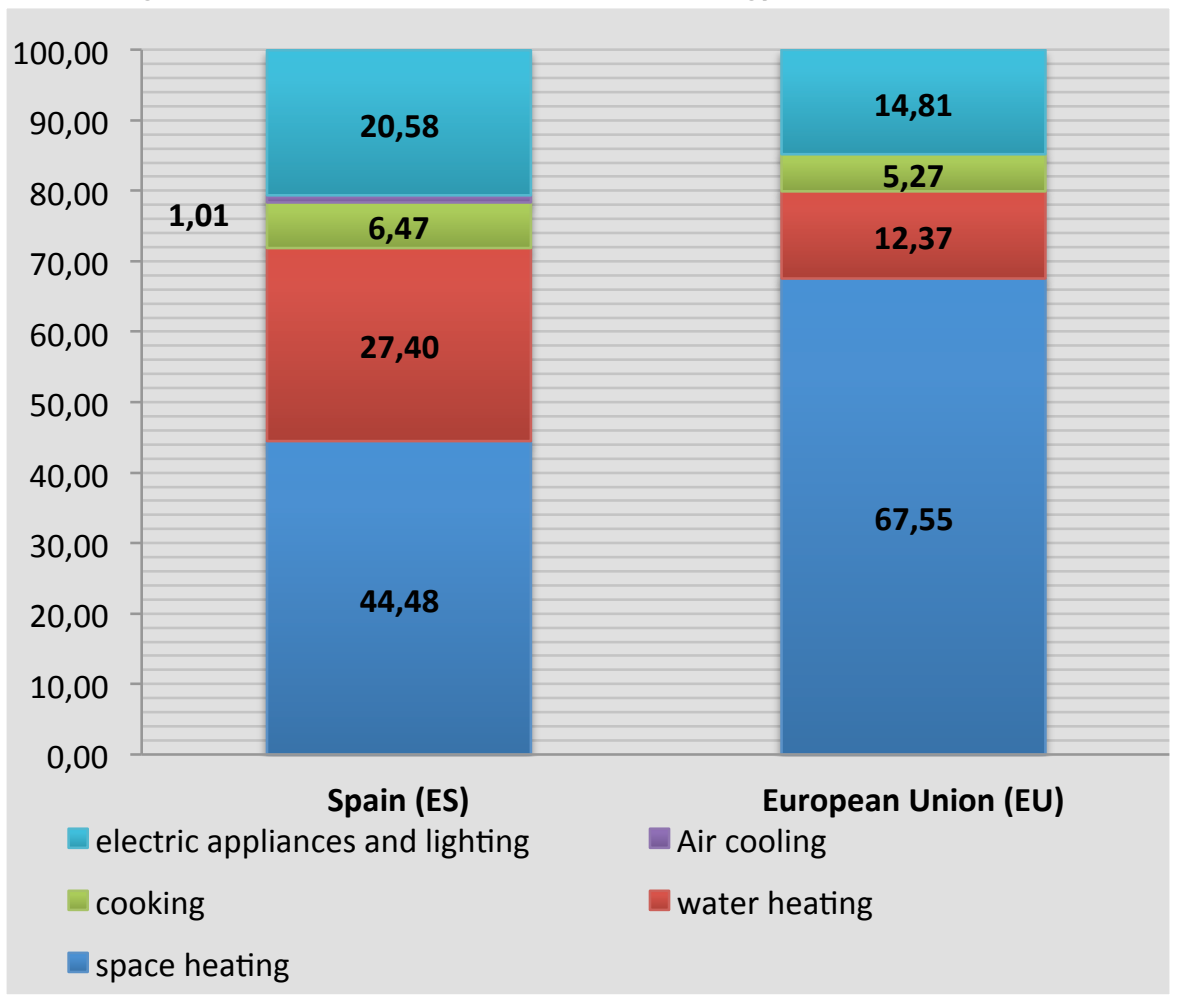

Source: Odyssee (2014)

Following the standard procedure to estimate models where the dependent variable takes binary values, we define a standard discrete choice probit model ${ }^{3}$ for each one of the appliances. The dependent variable is the probability of having an A or A+ label on the corresponding appliance. The probit model can be derived from an underlying latent variable model that satisfies the classical linear assumptions (Wooldridge, 2001). All we observe is whether the household has adopted a certain EE measure or not. However, we can assume that there is an unobserved or latent variable, $y_{i}^{*}$, that establishes a linear relation between our variables of interest as follows:

$$
y_{i}^{*}=\beta^{\prime} x_{i}+u_{i}=\propto+\theta X_{i}+\gamma G_{i}+\delta F_{i}+\rho A_{i}+\sigma E_{i}+u_{i}
$$

where $X_{i}$ is a vector with household $i$ socio-economic characteristics and $G_{i}$ is a vector to control the geographic variables previously described. Vector $F_{i}$ contains dummies for the type of fuel used and vector $A_{i}$ collects specific variables related to appliances, e.g. the age of the corresponding appliance. We further assume a normal distribution of the disturbances. Tables A1.1 and A1.2 (Annex I) describe all the additional variables and gives the associated statistics. Finally, $E_{i}$ represents the environmental measures of the household (see above).

Then, an indicator function can be defined so that $y_{i}$, our observable variable, equals one if $y_{i}^{*}>0$ and zero otherwise:

\footnotetext{
${ }^{3}$ An alternative would be to use a logit model, even though, probit models are generally employed in this type of econometric analysis. The results of both models are very similar, theoretically as well as in our application.
} 


$$
y_{i}=\left\{\begin{array}{l}
1 \text { if } y_{i}^{*}>0 \\
0 \text { if } y_{i}^{*} \leq 0
\end{array}\right.
$$

By substituting Equation (1) into (2), we can describe the probability of investment by household $i$ as follows:

$$
\operatorname{Prob}\left(y_{i}=1\right)=\operatorname{Prob}\left(y_{i}^{*}>0\right)=\operatorname{Prob}\left(u_{i}>-\beta^{\prime} x_{i}\right)
$$

Given the standard normal cumulative distribution function (.) of $u_{i}$, Equation (3) is rewritten as:

$$
\operatorname{Prob}\left(y_{i}=1\right)=\Phi\left(\beta^{\prime} x_{i}\right)=\Phi\left(\propto+\theta X_{i}+\gamma G_{i}+\delta F_{i}+\rho A_{i}+\sigma E_{i}+u_{i}\right)
$$

Equation (4) gives us the empirical magnitude of the effects of our explanatory variables on the probability of investing in a certain EE measure. This equation is repeated for each of the four appliances.

After looking at major appliances, we study the determinants of double-glazing EE investment. Despite being one of the measures with the highest energy-saving potentials, improving the insulation level of an existing building is one of the most difficult and costly measures (see Ürge-Vorsatz and Novika, 2008). However, installing double glazing does not require structural changes in buildings and therefore it could be one of the cheapest and easiest ways to improve the building envelope. In order to analyze the installation of double glazing, we now replace the dependent variable of Equation (4) by whether or not the household has installed double glazing. In addition, the specific vector for appliances characteristics, $A_{i}$, is replaced by another vector that is related to the acquisition of double glazing $\left(D_{i}\right)$. In particular, $D_{i}$ contains indicators for the availability of heating and air conditioning system. More information on these issues can be retrieved from Table A1.3 in Annex I.

The probability of having low consumption bulbs installed is the last dependent variable used to study EE investments. Unlike the preceding EE investment options, bulbs do not have high acquisition costs and long lifecycles. Yet, technical studies point out the high percentage of energy that can be saved in lighting through low-cost EE measures (see e.g. Levine et al., 2007) and this makes it an attractive area to foster EE improvements. As in previous models, we replace the dependent variable in Equation (4) by the probability of using low-consumption bulbs and eliminate the specific vector $D_{i}$. The rest of variables (socio-economic and environmental attitudes, geographic characteristics and type of fuel) are kept constant. More information on these questions can be obtained from Table A1.4 in Annex I.

\section{> Results on EE Investment}

Due to the non-linearity properties of these models, the interpretation of the coefficients in discrete choice frameworks is not straightforward. The complete regression output is provided in Annex II, together with the most used measures of goodness of fit: percentage of correctly predicted and pseudo R-squared (Wooldridge, 2001; Greene, 2008). For simplicity and easy interpretation, Table 3 only displays the signs of the coefficients in the EE investment models. The sign "+" means that the variable has a positive and statistically significant effect on the probability of having invested in the corresponding EE measure, while "-" refers to negative statistical significant effects on the same probability. 
Table 3. EE Investment Decisions of Spanish Households (probit model)

\begin{tabular}{|c|c|c|c|c|c|c|}
\hline \multirow[t]{2}{*}{ Dependent variable } & \multicolumn{4}{|c|}{$\begin{array}{c}\text { Appliances } \\
\text { (purchased over the last } 5 \text { years) }\end{array}$} & \multirow{2}{*}{$\begin{array}{l}\text { Double } \\
\text { glazing }\end{array}$} & \multirow{2}{*}{$\begin{array}{l}\text { Low- } \\
\text { consumption } \\
\text { bulbs }\end{array}$} \\
\hline & Fridge & $\begin{array}{l}\text { Washing } \\
\text { machine }\end{array}$ & Dishwasher & Oven & & \\
\hline TAX & . & - & . & . & . & + \\
\hline RENEWABLE & . & . & . & . & . & + \\
\hline RECYCLING & + & . & . & . & + & + \\
\hline POLITICAL & . & + & . & + & + & + \\
\hline $\begin{array}{l}\text { Continental (North } \\
\text { Atlantic as reference) }\end{array}$ & & & & & - & \\
\hline $\begin{array}{l}\text { Mediterranean (North } \\
\text { Atlantic as reference) }\end{array}$ & & & & & - & \\
\hline Spanish & + & + & + & + & + & + \\
\hline Unemployed & . & . & . & . & - & - \\
\hline Retired & - & . & . & . & - & . \\
\hline Educational level & + & + & + & + & + & + \\
\hline \#members & . & . & . & . & . & + \\
\hline \#members <16 & . & . & . & . & + & . \\
\hline \#member>65 & . & - & . & - & - & - \\
\hline Income & + & + & + & + & + & + \\
\hline $\begin{array}{l}\text { Age of the } \\
\text { corresponding } \\
\text { appliance }\end{array}$ & - & - & - & - & & \\
\hline $\begin{array}{l}\text { Availability of heating } \\
\text { system }\end{array}$ & & & & & + & \\
\hline $\begin{array}{l}\text { Availability of air } \\
\text { conditioning system }\end{array}$ & & & & & + & \\
\hline
\end{tabular}

Note: +(-) positive (negative) statistically significant effect of the explanatory variable on the probability of investment; shadow areas are variables that were not included in the regression. All regression contains dummy variables for regional areas, size of the municipality and type of energy used in the household. All regressions use heteroskedasticity-robust standard errors.

Income, Spanish nationality, education, and the presence of elderly people in the household are the socioeconomic variables with the most remarkable effects on the analyzed EE measures. All regressions show that households with higher income, Spanish nationality or higher educational levels are more likely to invest in EE, whereas four out of the five models indicate that the number of household members over 65 has a negative effect on EE investments. These income and age effects are expected, given the high costs and future paybacks associated with most EE investments, and they coincide with previous findings. With respect to Spanish nationality, the positive effect might be explained by different factors: the percentage of owneroccupied households is $82 \%$ for Spanish households, $43 \%$ for European citizens and less than $30 \%$ for nonEuropean citizens. . Since our data does not contain information on the ownership status, the positive effect of Spanish nationality could partially be due to the principal agent problem in rented-occupied households. Some other unobservable circumstances associated with foreign households, such as a higher difficulty to access information, might explain this effect. Results for other variables are inconclusive: employment status was not found to be statistically significant in all models, although it had the expected sign (unemployed or retired household's reference member show negative effects on the probability of EE investment). 
Regarding environmental measures, not all selected variables are statistically significant for all types of EE investments. The results from attitudinal and behavioral measures seems to diverge: while households that stated to be currently involved in environmental activities or practices are more likely to invest in EE in four out of six models, households who reported to be willing to pay to protect the environment have significantly higher probabilities in two regressions: for the acquisition of $A$ or $A+$ washing machine (negative effect) and for lowconsumption bulbs (positive effect). At first, one might expect that households willing to pay to protect the environment have stronger attitudes than those that only report participation in environmentally-friendly activities that do not necessarily imply a monetary cost. However, these activities might also be time intensive and thus related to non-negligible opportunity costs. Moreover, the stated WTP refers to hypothetical situations and could lead to wrong results (see e.g. Löschel et al., 2013). An explanation could be the so-called 'compliance bias' which makes respondents state a socially accepted WTP due to the influence of social norms (Green and Tunstall, 1999). This divergence runs in parallel with the results found by Lange et al. (2014) (see section 2).

Regarding the lack of significance for some measures, there are two more important factors: Appliances and windows are costly and replaced less frequently. Although eco-friendly consumers may be willing to substitute their inefficient appliances and windows, they may wait for the completion of their lifespan or may be subject to budget constraints, which may cause the lack of significance in some appliances. The second factor is related to the previously mentioned lack of data on ownership, which may lead to an underestimation if proenvironmental consumers are tenants because they would be less interested in major investments that would be lost when moving to another dwelling. When considering low-cost investment or absence of split incentives, as is the case with low-consumption bulbs, there is a clear positive effect even for the households with stated WTP measures. Yet, household environmental concerns seem to be less relevant for high-cost EE investments, suggesting the existence of a trade-off between environmental concerns and cost.

Finally, with respect to the characteristics of specific appliances, age is a major determining factor because appliances purchased over the last 5 years are less likely to have A or A+ labels as compared to those purchased over the last year. Similarly, households that have heating or air conditioning systems in most of the rooms are more likely to have double glazing, contrary to households in warmer areas (Continental and Mediterranean).

\section{> Robustness checks: multivariate probit regression}

The preceding results were based on baseline models that clearly display the drivers of EE investment, a major objective of the paper. Yet we are aware that household investment decisions among the evaluated measures could respond to common factors. Therefore, we next provide the results from the estimation of a multivariate probit model (similar to the seemingly unrelated model) to analyze possible correlations among the disturbances (Greene, 2008). In particular, this model is appropriate to estimate the probability of an individual purchasing several durables at the same moment of time. In our case, we could expect that the same factors moving a household to invest in EE appliances, could have led to the installation of double glazing and/or to the purchase of low-consumption bulbs too. To test the robustness of our results we estimate a system of equations where the disturbances follow a multivariate standard normal distribution. We use the previous equations for appliances, low consumption bulbs and double windows, to construct a system with three 
equations where the first equation refers to the probability of purchasing an $\mathrm{A}$ or $\mathrm{A}+\mathrm{fridg}^{4}$, and the subsequent two equations deal with the probability of purchasing double glazing and low-consumption bulbs respectively. Table 4 shows the directions of the effects (the results are displayed in Table A2.2, Annex II).

Table 4. EE Investment Decisions of Spanish Households (multivariate probit model)

\begin{tabular}{|l|c|c|c|}
\hline & Fridge & $\begin{array}{l}\text { Double } \\
\text { glazing }\end{array}$ & $\begin{array}{l}\text { Low- } \\
\text { consumption } \\
\text { bulbs }\end{array}$ \\
\hline TAX & $\cdot$ & $\cdot$ & $\cdot$ \\
\hline RENEWABLE & $\cdot$ & - & + \\
\hline RECYCLING & + & + & + \\
\hline POLITICAL & + & + & + \\
\hline Continental (North Atlantic as reference) & &. &. \\
\hline Mediterranean (North Atlantic as reference) & & - & + \\
\hline Spanish & + & + & + \\
\hline Unemployed & - & $\cdot$ &. \\
\hline Retired & - & $\cdot$ &. \\
\hline Educational level & $\mathbf{+}$ & $\mathbf{+}$ & $\mathbf{+}$ \\
\hline \#members & $\cdot$ & - & + \\
\hline \#members <16 & $\cdot$ & $\mathbf{+}$ &. \\
\hline \#member>65 & $\cdot$ & $\cdot$ & - \\
\hline Income & $\mathbf{+}$ & $\mathbf{+}$ & $\mathbf{+}$ \\
\hline Age of the corresponding appliance & - & & \\
\hline Availability of heating system & & $\mathbf{+}$ & \\
\hline Availability of air conditioning system & & $\mathbf{+}$ & \\
\hline
\end{tabular}

Notes: +(-) positive (negative) statistical significant effect of the explanatory variable on the probability of investment; shadow areas are variables that were not included in the regression. All regression contains dummy variables for regional areas, size of the municipality and type of energy used in the household. All regressions use heteroskedasticity-robust standard errors.

We cannot reject the null hypothesis of no correlation (see Annex II), which confirms the overall significance of the trivariate probit model. However, the significance and the sign of the effects of each variable remain mostly constant with respect to the baseline results ${ }^{5}$ (in particular the relationship between environmental attitudes and behaviors, and the probability of investing in $\mathrm{EE}$ ).

\subsection{Daily energy-saving habits}

We use winter indoor-heating temperature chosen by a household as a measure of its daily energy-saving habits, and expect pro-environmental households to set lower temperatures. This is an indication of household eco-friendly behavior that has been commonly employed by the literature (see e.g. Levinson and Niemann,

\footnotetext{
4 The database indicates that washing machines and fridges exist in most Spanish households. Therefore, computation was facilitated by the use of a trivariate probit model where fridge represented the purchase of appliance.

${ }^{5}$ We have rejected the inclusion of heteroskedasticity in our probit model as an additional robustness check, since a wrong functional form of the variances could lead to worse results.
} 
2004; Maruejolds et al., 2011; and Gillingham et al., 2012). Moreover, as Figure 1 indicates, space heating is the largest component of residential energy consumption in industrialized (as well as developing) countries and therefore a potentially important source of energy savings (Laustsen, 2008; European Commission, 2011).

In the ESHMA respondents are asked to report the Celsius degrees set in the heating thermostat on a normal day when at home. Following Gillingham et al. (2012) we construct a discrete variable that takes value 1 if the temperature stated by the respondent is less than or equal to $15^{\circ} \mathrm{C}$; value 2 if it falls between the interval 16$18^{\circ} \mathrm{C}$; value 3 for the interval between $19-21^{\circ} \mathrm{C}$; value 4 for the interval between $22-24^{\circ} \mathrm{C}$; value 5 for the interval between $25-27^{\circ} \mathrm{C}$; and value 6 for those temperatures equal or above $28^{\circ} \mathrm{C}$. Then we use an ordered probit model similar to Equation (4) to explain the effects of household socio-economic and environmental characteristics on the winter indoor-heating temperature while controlling for the rest of relevant factors. Table A1.5 (Annex I) contains a description of specific variables used in the regression ${ }^{6}$. However, Spain has large climatic differences across regions and our climatic zones might be too wide to collect all of these temperature differences. Since this may affect the intensity and frequency of residential heating use, we compare the results from the full sample with the results from a reduced sample. This reduced sample, as in Gillingham et al. (2012), considers only colder regions ${ }^{7}$.

\section{$>$ Results on daily energy-saving habits}

Following the same procedure as in the last section, Table 5 summarizes the main results for household winter indoor-heating temperature (full estimation results are again available in Annex II). Now sign "+" ("-") means that a variable has a positive (negative) statistically significant effect on the probability of increasing indoor temperature, thus being associated to less (more) energy-responsible habits. The two columns in Table 5 incorporate the two sample specifications: the full sample and a sample restricted to regions with average monthly temperatures below $19^{\circ} \mathrm{C}$. As indicated before, with this approach it is possible to test the significance of our results under different climatic conditions.

With regard to socio-economic characteristics, income and age are again two important determinants of indoor temperature. Households belonging to higher income levels are more likely to choose higher winter indoor temperature, as do households with members who are over 65 years of age. These results coincide with the findings in the literature; although contrary to other analyses, we have not found any significant effects of the number of children in the household. In addition, the educational levels show poor effects on heating temperature decisions. In the full sample specification, households where the reference member has primary education set lower temperature than those who are illiterate or did not finish primary education. However, in the reduced sample this coefficient loses their significance (see Annex II). The results suggest now that, contrary to EE investment, the level of education does not have an important effect on household energysaving habits. This means that households belonging to higher income levels or those with more education pay more attention to the EE attributes of products when taking investment decisions, although they do not follow the same considerations in their daily energy consumption habits.

\footnotetext{
${ }^{6}$ For the estimation of indoor heating temperatures we exclude the Autonomous Communities of Ceuta, Melilla and the Canary Islands given the important climatic differences with respect to the Iberian peninsula.

7 Based on Figure 2 we construct the reduced sample with those Autonomous Communities with monthly average temperatures below 19 in year 2008, which leads to the exclusion of Andalusia.
} 
Table 5. Energy-saving Habits: Targeted Heating Temperature

\begin{tabular}{|c|c|c|}
\hline Variable & Full sample & Only $<19^{\circ} \mathrm{C}$ \\
\hline TAX & 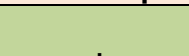 & \\
\hline RENEWABLE & . & \\
\hline RECYCLING & - & - \\
\hline POLITICAL & - & - \\
\hline Continental (North Atlantic as reference) & + & + \\
\hline Mediterranean (North Atlantic as reference) & + & + \\
\hline Spanish & . & . \\
\hline Unemployed & . & · \\
\hline Retired & . & . \\
\hline Educational level & $--^{*}$ & . \\
\hline \#members & . & . \\
\hline \#members $<16$ & . & . \\
\hline \#member>65 & + & + \\
\hline Income & + & + \\
\hline Heating in most of the rooms & - & - \\
\hline
\end{tabular}

Notes: +(-) positive (negative) statistical significant effect of the explanatory variable on the probability of increasing the temperature. All regression contains dummy variables for regional areas, size of the municipality, type of energy used in the household and by the heating device. ${ }^{*}$ Means not significant for all variable levels. All regressions use heteroskedasticity-robust standard errors.

Regarding environmental concerns, once again the effects from environmental attitudes diverge from that of environmentally-friendly behaviors. Households who would agree on imposing a penalty to the most pollutant fuels and those who reported a positive WTP for renewable energy do not exhibit differences in heating temperatures. The indexes measuring political activism in environmentally-related activities and recycling practices, however, have a negative effect on heating temperatures. That is, an increase of those two indexes is associated with lower heating temperatures. These results support our previous findings: environmental attitudes given by stated WTP do not translate into changes in daily energy consumption or high-cost EE investments. Environmentally-friendly behaviors, however, have a significant impact on EE habits and EE investments. Therefore, conclusions from environmental attitudes should be drawn very cautiously.

Even though geographic characteristics are not the focus of this paper, an analysis of the effects of climatic zones is especially interesting as existing evidence on temperature impacts is mixed. On the one hand, some authors have suggested that colder regions choose higher temperatures regardless of the associated higher costs (Friedman, 1987). On the other hand, other papers found the opposite (Dewees and Wilson, 1990; Gillingham et al., 2012). Our results coincide with the latter, indicating that the climatic zone variable has positive effects on indoor temperatures: households in warmer regions of the Continental and Mediterranean zones set higher heating temperatures as compared to households in the Atlantic area. This might be related to the fact that colder regions have higher marginal costs of heating. Given that housing size may matter (see, e.g. Gillingham et al., 2012), and although the ESHMA does not provide data on dwelling sizes, the dummy variable 'heating in most of the rooms' (equaling one when households have heating systems installed in most of the rooms) might be used as a proxy to study such effects. Again, our results indicate negative impacts for 
households with heating in most of the rooms. This reinforces the idea that colder regions and larger houses set lower temperatures due to higher marginal costs.

\section{Conclusions}

Buildings are a major source of energy consumption in both emerging and developed economies and thus a cause for public environmental and energy-dependence concerns. Contrary to other sectors, buildings are usually associated to a stock of future energy consumption that is mainly related to their design and structural characteristics and to behavioral decisions by the agents who use them. By acting in both areas, societies may achieve a sizable and cost-effective reduction of energy consumption in buildings. Proper building design and construction, retrofitting processes, replacement of old equipment by new EE appliances, and fostering energy conservation habits, are all essential for the success of EE strategies and plans. However, the progress of EE in the building sector has been rather limited due to the existence of numerous market barriers, such as imperfect information, split incentives or uncertainty, that result in a sub-optimal level of EE action. EE benefits, the importance of buildings in EE strategies, and market failures and barriers against EE, justify public intervention. However, public policies to promote EE should be defined and implemented with proper information on the agents' stances in this domain.

Consequently, prior to any policy initiative to incentivize consumers concerning certain products with desirable characteristics, policy-makers should carefully analyze what factors affect consumers EE-related decisions. In the special case of investing in EE or widespread adoption of daily energy-saving habits, policy-makers should identify the determinants that drive household decisions regarding these issues. With that objective in mind, using a Spanish representative household survey with detailed micro-data on environmental attitudes and behaviors, this paper empirically estimates the effects of certain socio-economic variables on the probability of investing in EE measures and adopting energy-saving habits. In particular, we study the effects of household environmental attitudes and behaviors on the probability of having installed double glazing, EE major appliances and low-consumption bulbs. Moreover, winter indoor temperature is used as a measure of daily energy-saving habits.

The paper showed that households with older members are less likely to invest in EE and show less ecofriendly habits. Moreover, household decisions on EE investments and energy-saving habits are driven by income levels in Spain: households with high income levels are more likely to invest in EE, although they are less likely to sacrifice comfort to save energy by setting lower heating temperatures. The same is true for higher education levels: households with more education pay more attention to the EE attributes of products when taking investment decisions, but they do not follow the same considerations in their daily energy consumption habits. Additionally, elderly households in Spain are less likely to invest in EE but have larger energy necessities for heating. This situation makes them more prone to the risk of suffering from fuel poverty, if they additionally belong to low-income groups. Our results also reveal an important time dimension of EE implementation: rising income and education levels might translate into energy savings through $\mathrm{EE}$

investments in the long run, but their more immediate effects might be rather small. Better information might stir EE investments, but will not necessarily lead to more energy-responsible habits. 
Additionally, environmental concerns are generally less important for high-cost investments with less frequent replacement and economic considerations seem to be predominant here. Also, reporting environmental attitudes does not show any effect on EE investment or energy-saving daily habits. However, households who currently develop eco-friendly practices, such as daily recycling or participating in environmental policy activism, are more likely to invest in EE and adopt daily energy-saving habits at home. This divergence might be explained, for instance, by 'compliance bias' produced when respondents report socially-desirable answers about some hypothetical situations. This indicates that environmental attitudes are not necessary translated into real actions.

In view of the increasing relevance of energy efficiency objectives and policies, the results of the paper have obvious implications that may be of interest beyond the Spanish case. Policies should first acknowledge that the factors that affect investment decisions in EE do not necessary influence the adoption of energy-saving habits in the same way. In this sense, our results show that, although public intervention aimed at reducing financial barriers seems to be key to promote EE investments by households with low income and/or with old members, other specific measures may be needed to foster their daily energy-saving habits. Moreover, the results of the paper suggest that EE-driven public campaigns may increase their effectiveness if they focus on the adoption of pro-environmental behaviors rather than on trying to raise environmental attitudes. 


\section{References}

Ameli, N., Brand, N. (2014). Determinants of households' investment in energy efficiency and renewables. Evidence from the OECD survey on household environmental behaviour and attitudes. OECD Economics Department working paper 1165.

Brechling, V., Smith, S. (1994). Household energy efficiency in the UK. Fiscal Studies 15: 44-56.

Brounen, D., Kok, N., Quigley, J.M. (2013). Energy literacy, awareness, and conservation behavior of residential households. Energy Economics 38: 42-50.

Costa, D.L., Kahn, M.E. (2010). Why has California's residential electricity consumption been so flat since the 1980s? NBER working paper 15978.

Davis, L. (2012). Evaluating the slow adoption of energy efficient investment: Are renters less likely to have energy efficient appliances? In Fullerton, D. and Wolfram, C. (eds.) The design and implementation of U.S. climate policy. University of Chicago Press, Chicago.

Dewees, D.N., Wilson, T.A. (1990). Cold Houses and warm climates revisited: On keeping warm in Chicago or paradox lost. Journal of Political Economy 98: 656-663.

Di Maria, C., Ferreira, S., Lazarova, E.A. (2008). Shedding light on the light bulb puzzle: Attitudes and perception. Scottish Journal of Political Economy 57: 48-67.

Ek, K., Söderholm, P. (2010). The devil is in the details: household electricity saving behavior and the role of information. Energy Policy 38: 1578-1587.

European Commission (2011). Energy efficiency plan. COM 109 final. Brussels.

Friedman, D. (1987). Cold houses in warm climates and vice versa: A paradox or rational heating. Journal of Political Economy 95: 1089-1097.

Gago, A., Hanemann, M., Labandeira, X., Ramos, A. (2013). Climate change, buildings and energy prices in Fouquet, R. (ed) Handbook on energy and climate change. Edward Elgar, Cheltenham.

Galarraga, I., González-Eguino, M., Markandya, A. (2011a). Willingness to pay and price elasticity of demand for energy-efficient appliances: combining the hedonic approach and demand systems. Energy Economics 33: S66-S74.

Galarraga, I., Heres, D.R., González-Eguino, M., (2011b). Price Premium for high-efficiency refrigerators and calculation of price-elasticities for close-substitutes: a methodology using hedonic pricing and demand systems. Journal of Cleaner Production, 19: 2057-2081.

Gillingham, K., Newell, R., Palmer, K. (2006). Energy efficiency policies: A retrospective examination. Annual Review of Environmental Resources 31: 161-192.

Gillingham, K., Newell, R., Palmer, K. (2009). Energy efficiency economics and policy. Annual Reviews of Environmental Resources 1: 597-620.

Gillingham, K., Harding, M., Rapson, D. (2012). Split incentives in residential energy consumption. Energy Journal 33: 37-62.

Green, C., Tunstall, S. (1999). A psychological perspective. In Bateman, I.J., Willis, K.G. (eds.). Valuing environmental preferences. Oxford University Press.

Greene, W.H. (2008). Econometric Analysis. Pearson, New York.

IDAE (2011). Proyecto SECH_SPAHOUSE: Análisis del consumo energético del sector residencial en España. Instituto para la Diversificación y Ahorro de la Energía, Madrid.

IEA (2007). Mind the gap. Quantifying principal-agent problems in energy efficiency. OECD/IEA, Paris. 
IEA (2013). Transition to sustainable buildings. Strategies and opportunities to 2050. OECD/IEA, Paris.

ESHMA, INE (2010). Encuesta de condiciones de vida 2008. Instituto Nacional de Estadística, Madrid.

Jaffe, A.B., Stavins, R.N. (1994). The energy-efficiency gap. What does it mean? Energy Policy 22: 804-810.

Kahn, M.E. (2007). Do greens drive hummers or hybrids? Environmental ideology as a determinant of consumer choice. Journal of Environmental Economics and Management 54: 129-145.

Kahn, M.E., Vaughn, R.K. (2009). Green market geography: The spatial clustering of hybrid vehicles and LEED registered buildings. The B.E. Journal of Economic Analysis and Policy 9.

Knack, S., Keefer, P. (1997). Does social capital have an economic payoff? A cross-country investigation. Quarterly Journal of Economics 112: 1251-1288.

Kollmuss, A., Agyeman, J. (2002). Mind the Gap: Why do people act environmentally and what are the barriers to pro-environmental behavior? Environmental Education Research, 8 (3): 239-260.

Kotchen, M.J., Moore, M.R. (2007). Private provision of environmental public goods: Household participation in green-electricity programs. Journal of Environmental Economics and Management 53: 1-16.

Laustsen, J. (2008). Energy efficiency requirements in building codes, Energy efficiency policies for new buildings. International Energy Agency, OECD, Paris.

Levine, M., Ürge-Vorsatz, D., Blok, K., Geng, L., Harvey, D., Lang, S., Levermore, G., Mongameli A., Mirasgedis, S., Novikova, A., Rilling, J., Yoshino, H. (2007). Residential and commercial buildings. In Climate Change 2007: Mitigation. Contribution of Working Group III to the Fourth Assessment Report of the Intergovernmental Panel on Climate Change.

Lange, I., Moro, M., Traynor, L. (2014). Green hypocrisy?: Environmental attitudes and residential space heating expenditure. Ecological Economics, 107: 76-83.

Levinson, A., Niemann, S. (2004). Energy use by apartment tenants when landlords pay for utilities. Resources and Energy Economics 26: 51-75.

Linares, P., Labandeira, X. (2010) Energy efficiency. Economics and policy. Journal of Economic Surveys 24: 573-592.

Löschel, A., Sturm, B., Vogt, C. (2013). The demand for climate protection. Empirical evidence from Germany. Economics Letters 118: 415-418.

Loureiro, M., Labandeira, X., Hanemann, M. (2013). Transport and low-carbon fuel: A study of public preferences in Spain. Energy Economics 40: S126-S133.

Markandya, A., Labandeira, X., Ramos, A. (2015). Policy instruments to foster energy efficiency. In Ansuategi, A., Delgado, J., Galarraga, I. (eds.) Green energy and efficiency. An economic perspective. Springer, Berlin.

Maruejols, L., Young, D. (2011). Split incentives and energy efficiency in Canadian multi-family dwellings. Energy Policy 39: 3655-3668.

Miller, K.H., Colantuoni, F., Cargo, C.L. (2014). An empirical analysis of residential energy efficiency adoption by housing types and occupancy. Paper presented at the 2014 AAEE Annual Meeting, Minneapolis.

Odyssee (2014). Database on energy efficiency indicators. Enerdata, London.

OECD (2013). Greening household behaviour: Overview from the 2011 survey. Technical report. OECD, Paris.

Owen, A., L., Videras, J. (2006). Civic cooperation, pro-environment attitudes, and behavioral intentions. Ecological Economics 58: 814-829.

Ryan, L., Moarif, S., Levina, E., Baron, R. (2011). Energy efficiency policy and carbon pricing. IEA Energy Efficiency Series, OECD, Paris. 
Torgler, B., García-Valiñas, M.A. (2007). The determinants of individuals' attitudes towards preventing environmental damage. Ecological Economics 63: 536-552.

Ürge-Vorsatz, D., Novika, A. (2008). Potentials and costs of carbon dioxide mitigation in the world's buildings. Energy Policy 36: 642-661.

Van den Bergh, J. (2008). Environmental regulation of households: An empirical review of economic and psychological factors. Ecological Economics 66: 559-574.

Vassileva, I., Wallin, F., Dahlquist, E. (2012). Understanding energy consumption behavior for future demand response strategy development. Energy 46: 94-100.

Wooldridge J.M. (2001). Econometric analysis of cross section and panel data. MIT Press, Cambridge MA. 


\section{ANNEX I: SUMMARY STATISTICS}

Table A1.1. Summary Statistics for Household Type of Fuel $\left(\boldsymbol{F}_{\boldsymbol{i}}\right)$

\begin{tabular}{|l|l|r|r|r|r|r|}
\hline Variable & Measurement & Observations & Mean & $\begin{array}{r}\text { Standard } \\
\text { deviation }\end{array}$ & Min. & Max. \\
\hline Electricity & Dummy & 26034 & 0.999 & 0.01 & 0 & 1 \\
\hline Solar & Dummy & 26034 & 0.009 & 0.09 & 0 & 1 \\
\hline Natural Gas & Dummy & 26034 & 0.379 & 0.48 & 0 & 1 \\
\hline LPG & Dummy & 26034 & 0.437 & 0.49 & 0 & 1 \\
\hline Wood & Dummy & 26034 & 0.074 & 0.26 & 0 & 1 \\
\hline Liquid fuels & Dummy & 26034 & 0.137 & 0.34 & 0 & 1 \\
\hline Other & Dummy & 26034 & 0.064 & 0.24 & 0 & 1 \\
\hline
\end{tabular}

Table A1.2. Summary Statistics for Specific Appliances Characteristics $\left(\boldsymbol{A}_{\boldsymbol{i}}\right)$

\begin{tabular}{|c|c|c|c|c|c|c|}
\hline Variable & Measurement & Observations & Mean & $\begin{array}{l}\text { Standard } \\
\text { deviation }\end{array}$ & Min. & Max. \\
\hline $\begin{array}{l}\text { Availability of } A \text { or } \\
A^{*} \text { fridge }\end{array}$ & Dummy & 17574 & 0.55 & 0.49 & 0 & 1 \\
\hline $\begin{array}{l}\text { Availability of } A \text { or } \\
A^{*} \text { fridge }\end{array}$ & Dummy & 17330 & 0.58 & 0.49 & 0 & 1 \\
\hline $\begin{array}{l}\text { Availability of } A \text { or } \\
A^{*} \text { fridge }\end{array}$ & Dummy & 8089 & 0.66 & 0.47 & 0 & 1 \\
\hline $\begin{array}{l}\text { Availability of } A \text { or } \\
A^{*} \text { fridge }\end{array}$ & Dummy & 14535 & 0.40 & 0.49 & 0 & 1 \\
\hline Age of Fridge & $\begin{array}{l}\text { Four-ascending } \\
\text { point-scale }\end{array}$ & 25999 & 2.71 & 0.90 & 1 & 4 \\
\hline $\begin{array}{l}\text { Age of Washing } \\
\text { machine }\end{array}$ & $\begin{array}{l}\text { Four-ascending } \\
\text { point-scale }\end{array}$ & 25809 & 2.57 & 0.89 & 1 & 4 \\
\hline $\begin{array}{l}\text { Age of } \\
\text { Dishwasher }\end{array}$ & $\begin{array}{l}\text { Four-ascending } \\
\text { point-scale }\end{array}$ & 11319 & 2.47 & 0.82 & 1 & 4 \\
\hline Age of Oven & $\begin{array}{l}\text { Four-ascending } \\
\text { point-scale }\end{array}$ & 23010 & 2.80 & 0.91 & 1 & 4 \\
\hline
\end{tabular}

Table A1.3. Summary Statistics for Specific Double-glazing Characteristics $\left(D_{i}\right)$

\begin{tabular}{|l|l|r|r|r|r|r|}
\hline Variable & Measurement & Observations & Mean & $\begin{array}{r}\text { Standard } \\
\text { deviation }\end{array}$ & Min. & Max. \\
\hline $\begin{array}{l}\text { Availability of } \\
\text { double glazing }\end{array}$ & Dummy & 26034 & 0.43 & 0.49 & 0 & 1 \\
\hline $\begin{array}{l}\text { Availability of } \\
\text { heating system }\end{array}$ & Dummy & 26034 & 0.73 & 0.44 & 0 & 1 \\
\hline $\begin{array}{l}\text { Availability of air } \\
\text { conditioning system }\end{array}$ & Dummy & 26034 & 0.30 & 0.46 & 0 & 1 \\
\hline
\end{tabular}


Table A1.4. Summary Statistics for Low-consumption Bulbs (LCB)

\begin{tabular}{|l|l|r|r|r|r|r|}
\hline Variable & Measurement & Observations & Mean & $\begin{array}{r}\text { Standard } \\
\text { deviation }\end{array}$ & Min. & Max. \\
\hline $\begin{array}{l}\text { Availability of } \\
\text { LCB }\end{array}$ & Dummy & 26034 & 0.65 & 0.48 & 0 & 1 \\
\hline
\end{tabular}

Table A1.5. Summary Statistics for Specific Heating Variables

\begin{tabular}{|l|l|r|r|r|r|r|}
\hline Variable & Measurement & Observations & Mean & $\begin{array}{r}\text { Standard } \\
\text { deviation }\end{array}$ & Min. & Max. \\
\hline $\begin{array}{l}\text { Individual } \\
\text { electric boiler }\end{array}$ & Dummy & 18911 & 0.059 & 0.236 & 0 & 1 \\
\hline Electric radiator & Dummy & 18911 & 0.212 & 0.410 & 0 & 1 \\
\hline $\begin{array}{l}\text { Underfloor } \\
\text { heating }\end{array}$ & Dummy & 18911 & 0.010 & 0.100 & 0 & 1 \\
\hline $\begin{array}{l}\text { Central gas } \\
\text { heating }\end{array}$ & Dummy & 18911 & 0.089 & 0.285 & 0 & 1 \\
\hline $\begin{array}{l}\text { Individual gas } \\
\text { heating }\end{array}$ & Dummy & 18911 & 0.325 & 0.488 & 0 & 1 \\
\hline Non-piped gas & Dummy & 18911 & 0.040 & 0.197 & 0 & 1 \\
\hline $\begin{array}{l}\text { Piped heat } \\
\text { pump }\end{array}$ & Dummy & 18911 & 0.026 & 0.157 & 0 & 1 \\
\hline $\begin{array}{l}\text { Non-piped heat } \\
\text { pump }\end{array}$ & Dummy & 18911 & 0.048 & 0.215 & 0 & 1 \\
\hline $\begin{array}{l}\text { Individual oil } \\
\text { heating }\end{array}$ & Dummy & 18911 & 0.105 & 0.307 & 0 & 1 \\
\hline $\begin{array}{l}\text { Central oil } \\
\text { heating }\end{array}$ & Dummy & 18911 & 0.075 & 0.264 & 0 & 1 \\
\hline $\begin{array}{l}\text { Central coal } \\
\text { heating }\end{array}$ & Dummy & 18911 & 0.004 & 0.066 & 0 & 1 \\
\hline Wood & Dummy & 18911 & 0.045 & 0.208 & 0 & 1 \\
\hline Other & Dummy & 18911 & 0.053 & 0.229 & 0 & 1 \\
\hline $\begin{array}{l}\text { Most rooms } \\
\text { with heating }\end{array}$ & Dummy & 18911 & 0.708 & 0.454 & 0 & 1 \\
\hline
\end{tabular}




\section{ANNEX II. REGRESSION RESULTS}

Table A2.1. Results for EE Investment (probit model)

\begin{tabular}{|c|c|c|c|c|c|c|}
\hline Variables & Fridge & $\begin{array}{l}\text { Washing } \\
\text { Machine }\end{array}$ & Dishwasher & Oven & Double glazing & $\begin{array}{l}\text { Low- } \\
\text { consumption } \\
\text { bulbs }\end{array}$ \\
\hline Spanish & $\begin{array}{l}0.291^{* * *} \\
(0.0861)\end{array}$ & $\begin{array}{l}0.288^{* * *} \\
(0.0818)\end{array}$ & $\begin{array}{l}0.267^{*} \\
(0.159)\end{array}$ & $\begin{array}{l}0.340^{* * *} \\
(0.0913)\end{array}$ & $\begin{array}{l}0.520^{\star * *} \\
(0.0499)\end{array}$ & $\begin{array}{l}0.443^{* * *} \\
(0.0438)\end{array}$ \\
\hline Unemployed & $\begin{array}{l}-0.0722 \\
(0.0628)\end{array}$ & $\begin{array}{c}-0.0390 \\
(0.0576)\end{array}$ & $\begin{array}{r}-0.00459 \\
(0.0919)\end{array}$ & $\begin{array}{c}-0.103 \\
(0.0649)\end{array}$ & $\begin{array}{c}-0.0776^{* *} \\
(0.0326)\end{array}$ & $\begin{array}{c}-0.0705^{\star *} \\
(0.0317)\end{array}$ \\
\hline Retired & $\begin{array}{c}-0.205^{\star * *} \\
(0.0613)\end{array}$ & $\begin{array}{c}-0.0295 \\
(0.0580) \\
\end{array}$ & $\begin{array}{c}-0.0798 \\
(0.0904)\end{array}$ & $\begin{array}{c}-0.0450 \\
(0.0634)\end{array}$ & $\begin{array}{c}-0.0884^{* * *} \\
(0.0323)\end{array}$ & $\begin{array}{l}-0.0630^{* *} \\
(0.0317)\end{array}$ \\
\hline Primary school & $\begin{array}{l}0.00806 \\
(0.0727)\end{array}$ & $\begin{array}{l}0.203^{* * *} \\
(0.0666)\end{array}$ & $\begin{array}{l}0.225^{*} \\
(0.122)\end{array}$ & $\begin{array}{l}0.227^{* * *} \\
(0.0769)\end{array}$ & $\begin{array}{l}0.256^{* * *} \\
(0.0343)\end{array}$ & $\begin{array}{l}0.330^{* * *} \\
(0.0312)\end{array}$ \\
\hline Secondary school 1st stage & $\begin{array}{c}-0.124 \\
(0.0897)\end{array}$ & $\begin{array}{c}0.0589 \\
(0.0808) \\
\end{array}$ & $\begin{array}{c}0.188 \\
(0.141)\end{array}$ & $\begin{array}{c}0.152 \\
(0.0945)\end{array}$ & $\begin{array}{l}0.305^{\star * *} \\
(0.0452)\end{array}$ & $\begin{array}{l}0.360^{* * *} \\
(0.0421)\end{array}$ \\
\hline Secondary school 2nd stage & $\begin{array}{c}0.0157 \\
(0.0883)\end{array}$ & $\begin{array}{l}0.219^{* * \star} \\
(0.0805)\end{array}$ & $\begin{array}{c}0.147 \\
(0.136)\end{array}$ & $\begin{array}{l}0.341^{* * *} \\
(0.0915)\end{array}$ & $\begin{array}{l}0.346^{* \star *} \\
(0.0445)\end{array}$ & $\begin{array}{l}0.466^{* * *} \\
(0.0427)\end{array}$ \\
\hline Vocational school & $\begin{array}{c}0.128 \\
(0.0912)\end{array}$ & $\begin{array}{l}0.350^{* * *} \\
(0.0828)\end{array}$ & $\begin{array}{l}0.320^{\star *} \\
(0.135)\end{array}$ & $\begin{array}{l}0.377^{* * *} \\
(0.0917)\end{array}$ & $\begin{array}{l}0.431^{* * *} \\
(0.0450)\end{array}$ & $\begin{array}{l}0.525^{* * *} \\
(0.0434)\end{array}$ \\
\hline University & $\begin{array}{c}0.146 \\
(0.0922)\end{array}$ & $\begin{array}{l}0.298^{* * *} \\
(0.0833)\end{array}$ & $\begin{array}{l}0.321^{* *} \\
(0.134)\end{array}$ & $\begin{array}{l}0.251^{* \star *} \\
(0.0914)\end{array}$ & $\begin{array}{l}0.422^{* * *} \\
(0.0454)\end{array}$ & $\begin{array}{l}0.623^{* * *} \\
(0.0443)\end{array}$ \\
\hline \#MEMBERS & $\begin{array}{l}-0.0349 \\
(0.0227)\end{array}$ & $\begin{array}{l}-0.0143 \\
(0.0212)\end{array}$ & $\begin{array}{l}-0.0464 \\
(0.0323)\end{array}$ & $\begin{array}{c}0.0171 \\
(0.0234)\end{array}$ & $\begin{array}{l}-0.00709 \\
(0.0120)\end{array}$ & $\begin{array}{l}0.0686^{* * *} \\
(0.0121)\end{array}$ \\
\hline \#MEMBER<16 & $\begin{array}{c}0.0320 \\
(0.0361)\end{array}$ & $\begin{array}{c}0.0409 \\
(0.0333) \\
\end{array}$ & $\begin{array}{c}0.0364 \\
(0.0457) \\
\end{array}$ & $\begin{array}{c}0.0170 \\
(0.0362)\end{array}$ & $\begin{array}{l}0.0905^{\star * *} \\
(0.0189)\end{array}$ & $\begin{array}{l}0.00782 \\
(0.0196)\end{array}$ \\
\hline \#MEMBER>65 & $\begin{array}{l}-0.00238 \\
(0.0378)\end{array}$ & $\begin{array}{l}-0.108^{* * *} \\
(0.0349)\end{array}$ & $\begin{array}{c}-0.0252 \\
(0.0577)\end{array}$ & $\begin{array}{l}-0.113^{\star * *} \\
(0.0395)\end{array}$ & $\begin{array}{c}-0.0590^{* * *} \\
(0.0189)\end{array}$ & $\begin{array}{l}-0.112^{* * *} \\
(0.0182)\end{array}$ \\
\hline 1.101-1.800€/month & $\begin{array}{l}0.182^{* * *} \\
(0.0539)\end{array}$ & $\begin{array}{l}0.0976^{*} \\
(0.0510)\end{array}$ & $\begin{array}{c}0.172^{\star *} \\
(0.0873)\end{array}$ & $\begin{array}{l}0.143^{* *} \\
(0.0582)\end{array}$ & $\begin{array}{l}0.230^{* * *} \\
(0.0283)\end{array}$ & $\begin{array}{l}0.198^{* * *} \\
(0.0271)\end{array}$ \\
\hline 1.801-2.700€/month & $\begin{array}{l}0.389^{* * *} \\
(0.0685)\end{array}$ & $\begin{array}{l}0.321^{* * *} \\
(0.0645)\end{array}$ & $\begin{array}{c}0.248^{\star *} \\
(0.0978)\end{array}$ & $\begin{array}{l}0.294^{* * *} \\
(0.0691)\end{array}$ & $\begin{array}{l}0.346^{* * *} \\
(0.0356)\end{array}$ & $\begin{array}{l}0.281^{* * *} \\
(0.0356)\end{array}$ \\
\hline$>2.700 € /$ month & $\begin{array}{l}0.361^{* * *} \\
(0.0825)\end{array}$ & $\begin{array}{l}0.341^{* * *} \\
(0.0779)\end{array}$ & $\begin{array}{l}0.264^{* *} \\
(0.108)\end{array}$ & $\begin{array}{l}0.314^{* * *} \\
(0.0817)\end{array}$ & $\begin{array}{l}0.401^{* * *} \\
(0.0440)\end{array}$ & $\begin{array}{l}0.281^{* * *} \\
(0.0445)\end{array}$ \\
\hline 10.000-20.000 inhab. & $\begin{array}{c}0.0142 \\
(0.0702) \\
\end{array}$ & $\begin{array}{c}0.0272 \\
(0.0648) \\
\end{array}$ & $\begin{array}{c}0.143 \\
(0.103) \\
\end{array}$ & $\begin{array}{c}-0.107 \\
(0.0709) \\
\end{array}$ & $\begin{array}{l}-0.0258 \\
(0.0360) \\
\end{array}$ & $\begin{array}{c}0.0213 \\
(0.0350)\end{array}$ \\
\hline 20.000-50.000 inhab. & $\begin{array}{c}0.122^{*} \\
(0.0686)\end{array}$ & $\begin{array}{c}0.0993 \\
(0.0632)\end{array}$ & $\begin{array}{c}0.0223 \\
(0.0939)\end{array}$ & $\begin{array}{c}-0.110 \\
(0.0680)\end{array}$ & $\begin{array}{l}-0.104^{* * *} \\
(0.0340)\end{array}$ & $\begin{array}{l}0.0587^{*} \\
(0.0331)\end{array}$ \\
\hline $50.000-100.000$ inhab. & $\begin{array}{l}-0.186^{* *} \\
(0.0760)\end{array}$ & $\begin{array}{l}-0.148^{* *} \\
(0.0720)\end{array}$ & $\begin{array}{l}-0.190^{*} \\
(0.107)\end{array}$ & $\begin{array}{l}-0.167^{* *} \\
(0.0811)\end{array}$ & $\begin{array}{l}-0.250^{* * *} \\
(0.0436)\end{array}$ & $\begin{array}{l}0.0795^{*} \\
(0.0413)\end{array}$ \\
\hline$>100.000$ inhab. & $\begin{array}{l}-0.0835 \\
(0.0575)\end{array}$ & $\begin{array}{c}0.0128 \\
(0.0543)\end{array}$ & $\begin{array}{c}0.0149 \\
(0.0805)\end{array}$ & $\begin{array}{l}-0.191^{* * *} \\
(0.0589)\end{array}$ & $\begin{array}{l}-0.199^{* * *} \\
(0.0298)\end{array}$ & $\begin{array}{l}0.0816^{\star * \star} \\
(0.0288)\end{array}$ \\
\hline Continental & & & & & $\begin{array}{l}-0.359^{* * *} \\
(0.0658)\end{array}$ & \\
\hline Mediterranean & & & & & $\begin{array}{l}-0.769^{* * *} \\
(0.0428)\end{array}$ & \\
\hline Appliance age & $\begin{array}{l}-0.661^{* * *} \\
(0.0642)\end{array}$ & $\begin{array}{l}-0.683^{\star * *} \\
(0.0581)\end{array}$ & $\begin{array}{c}-0.745^{\star * *} \\
(0.0984)\end{array}$ & $\begin{array}{l}-0.513^{\star * *} \\
(0.0573)\end{array}$ & & \\
\hline
\end{tabular}




\begin{tabular}{|c|c|c|c|c|c|c|}
\hline Heating & & & & & $\begin{array}{l}0.351^{\star * *} \\
(0.0290)\end{array}$ & \\
\hline Air conditioning & & & & & $\begin{array}{l}0.249^{* * *} \\
(0.0286)\end{array}$ & \\
\hline TAX & $\begin{array}{c}0.0575 \\
(0.0426) \\
\end{array}$ & $\begin{array}{c}-0.0689^{*} \\
(0.0407)\end{array}$ & $\begin{array}{l}-0.0338 \\
(0.0607) \\
\end{array}$ & $\begin{array}{c}-0.0225 \\
(0.0439) \\
\end{array}$ & $\begin{array}{c}-0.000197 \\
(0.0221) \\
\end{array}$ & $\begin{array}{l}0.104^{* * *} \\
(0.0214)\end{array}$ \\
\hline RENEWABLE & $\begin{array}{c}-0.0434 \\
(0.0476) \\
\end{array}$ & $\begin{array}{c}0.0344 \\
(0.0446) \\
\end{array}$ & $\begin{array}{l}0.00223 \\
(0.0641) \\
\end{array}$ & $\begin{array}{c}0.0279 \\
(0.0476) \\
\end{array}$ & $\begin{array}{c}-0.0180 \\
(0.0249) \\
\end{array}$ & $\begin{array}{l}0.0620^{* *} \\
(0.0250)\end{array}$ \\
\hline RECYCLING & $\begin{array}{c}0.0495^{\star \star \star} \\
(0.0157)\end{array}$ & $\begin{array}{c}0.0249 \\
(0.0152) \\
\end{array}$ & $\begin{array}{c}0.0192 \\
(0.0233) \\
\end{array}$ & $\begin{array}{c}0.0196 \\
(0.0169) \\
\end{array}$ & $\begin{array}{l}0.0536^{\star * *} \\
(0.00812)\end{array}$ & $\begin{array}{l}0.0857^{\star * \star} \\
(0.00762)\end{array}$ \\
\hline ACTIVISM & $\begin{array}{c}0.0342 \\
(0.0266) \\
\end{array}$ & $\begin{array}{c}0.0750^{* * *} \\
(0.0269)\end{array}$ & $\begin{array}{c}0.0208 \\
(0.0353) \\
\end{array}$ & $\begin{array}{c}0.0418^{c} \\
(0.0268)\end{array}$ & $\begin{array}{c}0.0714^{* * *} \\
(0.0145)\end{array}$ & $\begin{array}{l}0.132^{* * *} \\
(0.0165)\end{array}$ \\
\hline Solar & $\begin{array}{l}-0.245 \\
(0.182) \\
\end{array}$ & $\begin{array}{c}0.225 \\
(0.206) \\
\end{array}$ & $\begin{array}{l}-0.0675 \\
(0.217)\end{array}$ & $\begin{array}{c}0.285 \\
(0.218) \\
\end{array}$ & $\begin{array}{l}0.427^{* * *} \\
(0.123)\end{array}$ & $\begin{array}{l}0.349^{* *} \\
(0.137)\end{array}$ \\
\hline Piped gas & $\begin{array}{c}-0.0516 \\
(0.0631)\end{array}$ & $\begin{array}{r}-0.00210 \\
(0.0587)\end{array}$ & $\begin{array}{l}-0.0118 \\
(0.0880)\end{array}$ & $\begin{array}{c}-0.0971 \\
(0.0609)\end{array}$ & $\begin{array}{c}0.0993^{* * *} \\
(0.0315)\end{array}$ & $\begin{array}{c}0.0362 \\
(0.0316)\end{array}$ \\
\hline LPG & $\begin{array}{c}-0.174^{* * *} \\
(0.0626)\end{array}$ & $\begin{array}{c}-0.0230 \\
(0.0583)\end{array}$ & $\begin{array}{l}-0.0300 \\
(0.0948)\end{array}$ & $\begin{array}{l}-0.213^{\star * *} \\
(0.0634)\end{array}$ & $\begin{array}{l}-0.369^{* * *} \\
(0.0308)\end{array}$ & $\begin{array}{l}-0.149^{* * *} \\
(0.0307)\end{array}$ \\
\hline Wood & $\begin{array}{c}-0.0232 \\
(0.0880)\end{array}$ & $\begin{array}{c}0.0476 \\
(0.0813)\end{array}$ & $\begin{array}{l}0.224^{*} \\
(0.135)\end{array}$ & $\begin{array}{c}-0.0293 \\
(0.0950)\end{array}$ & $\begin{array}{c}0.0516 \\
(0.0423)\end{array}$ & $\begin{array}{c}0.0364 \\
(0.0404) \\
\end{array}$ \\
\hline Liquid fuels & $\begin{array}{c}0.0771 \\
(0.0727) \\
\end{array}$ & $\begin{array}{c}0.152^{* *} \\
(0.0687)\end{array}$ & $\begin{array}{l}0.212^{* *} \\
(0.101)\end{array}$ & $\begin{array}{c}0.0672 \\
(0.0733) \\
\end{array}$ & $\begin{array}{l}0.173^{* * *} \\
(0.0352)\end{array}$ & $\begin{array}{l}0.156^{* * *} \\
(0.0349) \\
\end{array}$ \\
\hline Other & $\begin{array}{c}0.0276 \\
(0.0923) \\
\end{array}$ & $\begin{array}{l}0.00972 \\
(0.0857)\end{array}$ & $\begin{array}{l}0.0988 \\
(0.137)\end{array}$ & $\begin{array}{c}0.0218 \\
(0.0954)\end{array}$ & $\begin{array}{c}0.0784^{*} \\
(0.0446) \\
\end{array}$ & $\begin{array}{c}0.103^{* *} \\
(0.0444)\end{array}$ \\
\hline Constant & $\begin{array}{c}1.080^{* * *} \\
(0.164) \\
\end{array}$ & $\begin{array}{c}0.867^{\star \star \star} \\
(0.149)\end{array}$ & $\begin{array}{c}1.023^{\star * \star} \\
(0.262)\end{array}$ & $\begin{array}{l}0.409^{\star \star} \\
(0.167)\end{array}$ & $\begin{array}{c}-0.988^{* * *} \\
(0.0795)\end{array}$ & $\begin{array}{c}-0.920^{* * *} \\
(0.0739)\end{array}$ \\
\hline $\begin{array}{c}\text { McFadden Pseudo R2 } \\
\% \text { of correct prediction } \\
\text { Overall significant test: } \\
\text { p-value }\end{array}$ & $\begin{array}{c}0.079 \\
84.8 \% \\
0.000\end{array}$ & $\begin{array}{c}0.082 \\
84.2 \% \\
0.000\end{array}$ & $\begin{array}{l}0.077 \\
86.9 \% \\
0.000\end{array}$ & $\begin{array}{c}0.076 \\
72.4 \% \\
0.000\end{array}$ & $\begin{array}{c}0.178 \\
70.7 \% \\
0.000\end{array}$ & $\begin{array}{c}0.103 \\
70.5 \% \\
0.000\end{array}$ \\
\hline Observations & 6,459 & 7,225 & 3,617 & 4,761 & 18,015 & 18,015 \\
\hline
\end{tabular}

Note: Robust standard errors in parentheses, ${ }^{* * *} p<0.01,{ }^{* *} p<0.05,{ }^{*} p<0.1 .{ }^{c} p<0.11$

Table A2.2 Results for EE Investment (multivariate probit model)

\begin{tabular}{|c|c|c|c|}
\hline Variables & $\begin{array}{c}\text { A or A+ } \\
\text { Fridge }\end{array}$ & $\begin{array}{l}\text { Double } \\
\text { glazing }\end{array}$ & $\begin{array}{l}\text { Low- } \\
\text { consumptiom } \\
\text { bulbs }\end{array}$ \\
\hline Spanish & $\begin{array}{c}0.374^{\star \star *} \\
(0.100)\end{array}$ & $\begin{array}{l}0.369^{\star \star \star} \\
(0.0914)\end{array}$ & $\begin{array}{l}0.319^{\star \star *} \\
(0.0902)\end{array}$ \\
\hline Unemployed & $\begin{array}{c}-0.145^{*} \\
(0.0835)\end{array}$ & $\begin{array}{c}0.0743 \\
(0.0707)\end{array}$ & $\begin{array}{l}-0.0122 \\
(0.0741)\end{array}$ \\
\hline Retired & $\begin{array}{l}-0.221^{* * *} \\
(0.0835)\end{array}$ & $\begin{array}{c}-0.115 \\
(0.0754)\end{array}$ & $\begin{array}{l}0.00869 \\
(0.0784)\end{array}$ \\
\hline Primary school & $\begin{array}{l}0.0689 \\
(0.105)\end{array}$ & $\begin{array}{l}0.300^{* * *} \\
(0.0925)\end{array}$ & $\begin{array}{l}0.364^{* \star *} \\
(0.0911)\end{array}$ \\
\hline
\end{tabular}




\begin{tabular}{|c|c|c|c|}
\hline Secondary school 1st stage & $\begin{array}{c}-0.0414 \\
(0.122)\end{array}$ & $\begin{array}{l}0.233^{* *} \\
(0.109)\end{array}$ & $\begin{array}{c}0.380^{\star * *} \\
(0.108)\end{array}$ \\
\hline Secondary school 2nd stage & $\begin{array}{c}0.00831 \\
(0.120) \\
\end{array}$ & $\begin{array}{c}0.414^{* * *} \\
(0.105)\end{array}$ & $\begin{array}{c}0.369^{* * *} \\
(0.106)\end{array}$ \\
\hline Vocational school & $\begin{array}{l}0.212^{*} \\
(0.126)\end{array}$ & $\begin{array}{c}0.365^{\star * *} \\
(0.106)\end{array}$ & $\begin{array}{c}0.471^{* * *} \\
(0.107)\end{array}$ \\
\hline University & $\begin{array}{c}0.172 \\
(0.127)\end{array}$ & $\begin{array}{c}0.375^{\star * *} \\
(0.107)\end{array}$ & $\begin{array}{c}0.603^{* * *} \\
(0.109)\end{array}$ \\
\hline \#MEMBERS & $\begin{array}{l}-0.0483 \\
(0.0303)\end{array}$ & $\begin{array}{c}-0.0689^{* * *} \\
(0.0261)\end{array}$ & $\begin{array}{c}0.0866^{* * *} \\
(0.0276)\end{array}$ \\
\hline \#MEMBERS $<16$ & $\begin{array}{c}0.0704 \\
(0.0490)\end{array}$ & $\begin{array}{l}0.0959^{* *} \\
(0.0402)\end{array}$ & $\begin{array}{c}-0.0296 \\
(0.0437)\end{array}$ \\
\hline \#MEMBERS $>65$ & $\begin{array}{c}0.0718 \\
(0.0546) \\
\end{array}$ & $\begin{array}{l}-0.0713 \\
(0.0478) \\
\end{array}$ & $\begin{array}{c}-0.130^{* * *} \\
(0.0485) \\
\end{array}$ \\
\hline 1.101-1.800€/month & $\begin{array}{c}0.170^{* *} \\
(0.0738)\end{array}$ & $\begin{array}{l}0.204^{* * *} \\
(0.0652)\end{array}$ & $\begin{array}{l}0.223^{* * *} \\
(0.0646)\end{array}$ \\
\hline $1.801-2.700 € /$ month & $\begin{array}{l}0.414^{\star \star \star} \\
(0.0925)\end{array}$ & $\begin{array}{l}0.516^{\star * *} \\
(0.0768)\end{array}$ & $\begin{array}{l}0.423^{\star * \star} \\
(0.0790)\end{array}$ \\
\hline$>2.700 € /$ month & $\begin{array}{c}0.403^{* * *} \\
(0.111)\end{array}$ & $\begin{array}{l}0.466^{* * *} \\
(0.0917)\end{array}$ & $\begin{array}{l}0.364^{* \star *} \\
(0.0943)\end{array}$ \\
\hline 10.000-20.000 inhab. & $\begin{array}{c}-0.00564 \\
(0.0935)\end{array}$ & $\begin{array}{l}-0.0144 \\
(0.0784)\end{array}$ & $\begin{array}{l}-0.0617 \\
(0.0799)\end{array}$ \\
\hline 20.000-50.000 inhab. & $\begin{array}{c}0.0282 \\
(0.0901)\end{array}$ & $\begin{array}{c}-0.204^{* * *} \\
(0.0737)\end{array}$ & $\begin{array}{c}-0.0842 \\
(0.0761) \\
\end{array}$ \\
\hline $50.000-100.000$ inhab. & $\begin{array}{c}-0.266^{* * *} \\
(0.102)\end{array}$ & $\begin{array}{r}-0.309^{* \star *} \\
(0.0908) \\
\end{array}$ & $\begin{array}{c}-0.0157 \\
(0.0940)\end{array}$ \\
\hline$>100.000$ inhab. & $\begin{array}{l}-0.176^{* *} \\
(0.0757) \\
\end{array}$ & $\begin{array}{c}-0.278^{* * *} \\
(0.0653) \\
\end{array}$ & $\begin{array}{c}-0.0243 \\
(0.0669) \\
\end{array}$ \\
\hline Continental & & $\begin{array}{l}-0.160 \\
(0.315)\end{array}$ & $\begin{array}{c}0.366 \\
(0.322) \\
\end{array}$ \\
\hline Mediterranean & & $\begin{array}{c}-0.763^{* \star *} \\
(0.247)\end{array}$ & $\begin{array}{l}0.490^{* *} \\
(0.248)\end{array}$ \\
\hline TAX & $\begin{array}{c}0.0432 \\
(0.0572)\end{array}$ & $\begin{array}{l}0.00780 \\
(0.0487)\end{array}$ & $\begin{array}{c}0.0515 \\
(0.0501)\end{array}$ \\
\hline WTP & $\begin{array}{c}-0.0337 \\
(0.0631)\end{array}$ & $\begin{array}{c}-0.101^{*} \\
(0.0518)\end{array}$ & $\begin{array}{c}0.131^{* *} \\
(0.0557)\end{array}$ \\
\hline RECICLA & $\begin{array}{l}0.0375^{*} \\
(0.0205)\end{array}$ & $\begin{array}{c}0.0471^{* * *} \\
(0.0177)\end{array}$ & $\begin{array}{c}0.0515^{\star * *} \\
(0.0188)\end{array}$ \\
\hline POLITICAL & $\begin{array}{l}0.0581^{*} \\
(0.0344)\end{array}$ & $\begin{array}{l}0.0611^{* *} \\
(0.0271)\end{array}$ & $\begin{array}{l}0.106^{* * *} \\
(0.0325)\end{array}$ \\
\hline Solar & $\begin{array}{l}-0.403^{*} \\
(0.235)\end{array}$ & $\begin{array}{l}-0.0960 \\
(0.216) \\
\end{array}$ & $\begin{array}{l}-0.0848 \\
(0.241) \\
\end{array}$ \\
\hline Piped gas & $\begin{array}{l}-0.0333 \\
(0.0842)\end{array}$ & $\begin{array}{c}0.0581 \\
(0.0672)\end{array}$ & $\begin{array}{c}0.0140 \\
(0.0701)\end{array}$ \\
\hline LPG & $\begin{array}{l}-0.246^{* * *} \\
(0.0849)\end{array}$ & $\begin{array}{c}-0.320^{* * *} \\
(0.0673)\end{array}$ & $\begin{array}{l}-0.179^{* *} \\
(0.0724)\end{array}$ \\
\hline Wood & $\begin{array}{l}-0.0991 \\
(0.119) \\
\end{array}$ & $\begin{array}{l}0.0361 \\
(0.101) \\
\end{array}$ & $\begin{array}{c}0.113 \\
(0.108) \\
\end{array}$ \\
\hline Liquid fuels & $\begin{array}{c}0.0740 \\
(0.0998)\end{array}$ & $\begin{array}{c}0.0348 \\
(0.0830)\end{array}$ & $\begin{array}{c}0.0611 \\
(0.0873)\end{array}$ \\
\hline
\end{tabular}




\begin{tabular}{|c|c|c|c|c|}
\hline Other & & $\begin{array}{l}-0.0410 \\
(0.123)\end{array}$ & $\begin{array}{c}0.0632 \\
(0.0970)\end{array}$ & $\begin{array}{l}0.191^{*} \\
(0.109)\end{array}$ \\
\hline bCAL & & & $\begin{array}{l}0.323^{* * *} \\
(0.0655)\end{array}$ & \\
\hline bAIRE & & & $\begin{array}{l}0.176^{\star * *} \\
(0.0620)\end{array}$ & \\
\hline electa2 & & $\begin{array}{l}-0.688^{* * *} \\
(0.0960)\end{array}$ & & \\
\hline Constant & & $\begin{array}{c}1.248^{* * *} \\
(0.217)\end{array}$ & $\begin{array}{c}-0.354 \\
(0.288)\end{array}$ & $\begin{array}{c}-0.947^{* * *} \\
(0.288)\end{array}$ \\
\hline rho21 & $\begin{array}{l}0.0681^{* *} \\
(0.0311)\end{array}$ & & & \\
\hline rho31 & $\begin{array}{l}0.162^{\star * \star} \\
(0.0315)\end{array}$ & & & \\
\hline rho32 & $\begin{array}{l}0.137^{* * *} \\
(0.0288)\end{array}$ & & & \\
\hline Observations & & 3,754 & 3,754 & 3,754 \\
\hline
\end{tabular}

Note: Robust standard errors in parentheses ${ }^{* * *} p<0.01,{ }^{* *} p<0.05,{ }^{*} p<0.1$

Table A2.3. Results for Winter Indoor-heating Temperatures

\begin{tabular}{|l|c|c|}
\hline & Full sample & Reduced sample \\
\hline Spanish & 0.0233 & 0.0114 \\
& $(0.0750)$ & $(0.0786)$ \\
\hline Unemployed & 0.00766 & 0.00485 \\
& $(0.0401)$ & $(0.0428)$ \\
\hline Retired & -0.0230 & -0.0169 \\
& $(0.0383)$ & $(0.0397)$ \\
\hline Primary school & $-0.0826^{*}$ & -0.0659 \\
& $(0.0460)$ & $(0.0477)$ \\
\hline Secondary school 1st stage & -0.0299 & -0.0227 \\
& $(0.0608)$ & $(0.0657)$ \\
\hline Secondary school 2nd stage & -0.0307 & -0.00575 \\
& $(0.0557)$ & $(0.0583)$ \\
\hline Vocational school & -0.0567 & -0.0534 \\
& $(0.0548)$ & $(0.0572)$ \\
\hline University & -0.0741 & -0.0290 \\
& $(0.0548)$ & $(0.0572)$ \\
\hline \#MEMBERS & 0.00525 & -0.00444 \\
& $(0.0146)$ & $(0.0151)$ \\
\hline \#MEMBER<16 & -0.00967 & -0.0106 \\
& $(0.0204)$ & $(0.0214)$ \\
\hline \#MEMBER>65 & $0.0535^{\star *}$ & $0.0566^{* *}$ \\
& $(0.0230)$ & $(0.0240)$ \\
\hline 1.101-1.800€/month & 0.0561 & $0.0678^{*}$ \\
& $(0.0360)$ & $(0.0375)$ \\
\hline $1.801-2.700 € / m o n t h$ & $0.133^{* * *}$ & $0.162^{* * *}$ \\
& $(0.0426)$ & $(0.0444)$ \\
\hline
\end{tabular}




\begin{tabular}{|c|c|c|}
\hline$>2.700 € /$ month & $\begin{array}{l}0.0886^{*} \\
(0.0487)\end{array}$ & $\begin{array}{c}0.101^{* *} \\
(0.0512) \\
\end{array}$ \\
\hline 10.000-20.000 inhab. & $\begin{array}{c}0.0531 \\
(0.0427)\end{array}$ & $\begin{array}{c}0.0418 \\
(0.0442)\end{array}$ \\
\hline 20.000-50.000 inhab. & $\begin{array}{c}0.0581 \\
(0.0399) \\
\end{array}$ & $\begin{array}{c}0.0689^{*} \\
(0.0417)\end{array}$ \\
\hline 50.000-100.000 inhab. & $\begin{array}{l}0.237^{* \star *} \\
(0.0495)\end{array}$ & $\begin{array}{l}0.234^{* * *} \\
(0.0521)\end{array}$ \\
\hline$>100.000$ hab. & $\begin{array}{l}0.320^{* * *} \\
(0.0348)\end{array}$ & $\begin{array}{l}0.308^{* * *} \\
(0.0360)\end{array}$ \\
\hline Continental & $\begin{array}{l}0.354^{* * *} \\
(0.0749)\end{array}$ & $\begin{array}{l}0.475^{* * *} \\
(0.0669)\end{array}$ \\
\hline Mediterranean & $\begin{array}{l}1.349^{* * *} \\
(0.0636)\end{array}$ & $\begin{array}{l}1.500^{* * *} \\
(0.0618)\end{array}$ \\
\hline Most rooms with heating & $\begin{array}{l}-0.157^{\star \star *} \\
(0.0401)\end{array}$ & $\begin{array}{l}-0.104^{* *} \\
(0.0441)\end{array}$ \\
\hline TAX & $\begin{array}{c}0.0280 \\
(0.0252)\end{array}$ & $\begin{array}{c}0.0431 \\
(0.0263)\end{array}$ \\
\hline WTP & $\begin{array}{l}-0.0258 \\
(0.0274)\end{array}$ & $\begin{array}{l}-0.0297 \\
(0.0287)\end{array}$ \\
\hline RECICLA & $\begin{array}{c}-0.0397^{* * *} \\
(0.0104)\end{array}$ & $\begin{array}{c}-0.0432^{* * *} \\
(0.0110)\end{array}$ \\
\hline POLITICAL & $\begin{array}{c}-0.0412^{* * *} \\
(0.0154)\end{array}$ & $\begin{array}{c}-0.0373^{* *} \\
(0.0158)\end{array}$ \\
\hline Piped gas & $\begin{array}{l}-0.00912 \\
(0.0487)\end{array}$ & $\begin{array}{r}-0.00835 \\
(0.0522) \\
\end{array}$ \\
\hline LPG & $\begin{array}{l}0.0721^{*} \\
(0.0401)\end{array}$ & $\begin{array}{c}0.0533 \\
(0.0425) \\
\end{array}$ \\
\hline Wood & $\begin{array}{l}-0.280^{* * *} \\
(0.0929)\end{array}$ & $\begin{array}{l}-0.240^{* *} \\
(0.103)\end{array}$ \\
\hline Liquid fuels & $\begin{array}{l}-0.226^{*} \\
(0.133)\end{array}$ & $\begin{array}{l}-0.142 \\
(0.145)\end{array}$ \\
\hline Other & $\begin{array}{l}-0.0501 \\
(0.0596)\end{array}$ & $\begin{array}{c}0.0154 \\
(0.0650) \\
\end{array}$ \\
\hline Individual electric boiler & $\begin{array}{l}-0.0572 \\
(0.0568)\end{array}$ & $\begin{array}{c}-0.0822 \\
(0.0621)\end{array}$ \\
\hline Electric radiator & $\begin{array}{l}-0.140^{* * *} \\
(0.0481)\end{array}$ & $\begin{array}{c}-0.150^{\star \star \star} \\
(0.0517) \\
\end{array}$ \\
\hline Underfloor heating & $\begin{array}{l}-0.0928 \\
(0.105) \\
\end{array}$ & $\begin{array}{l}-0.0846 \\
(0.109) \\
\end{array}$ \\
\hline Central gas heating & $\begin{array}{l}-0.0742 \\
(0.0637) \\
\end{array}$ & $\begin{array}{c}-0.0754 \\
(0.0672) \\
\end{array}$ \\
\hline Individual gas heating & $\begin{array}{l}-0.169^{* \star \star} \\
(0.0561)\end{array}$ & $\begin{array}{c}-0.168^{\star \star \star} \\
(0.0598)\end{array}$ \\
\hline Non-piped gas & $\begin{array}{l}-0.375^{* * *} \\
(0.0948)\end{array}$ & $\begin{array}{c}-0.341^{* * *} \\
(0.101)\end{array}$ \\
\hline Pipe heat pump & $\begin{array}{l}0.307^{* * *} \\
(0.0691)\end{array}$ & $\begin{array}{l}0.308^{* * *} \\
(0.0757)\end{array}$ \\
\hline Non-piped heat pump & $\begin{array}{l}0.284^{* * *} \\
(0.0644)\end{array}$ & $\begin{array}{l}0.241^{* * *} \\
(0.0702)\end{array}$ \\
\hline
\end{tabular}




\begin{tabular}{|c|c|c|}
\hline Individual oil heating & $\begin{array}{c}-0.0904 \\
(0.140)\end{array}$ & $\begin{array}{l}-0.118 \\
(0.151)\end{array}$ \\
\hline Central oil heating & $\begin{array}{l}0.320^{* *} \\
(0.144)\end{array}$ & $\begin{array}{l}0.258^{*} \\
(0.155)\end{array}$ \\
\hline Central coal heating & $\begin{array}{l}-0.555 \\
(0.411)\end{array}$ & $\begin{array}{l}-0.622 \\
(0.413)\end{array}$ \\
\hline Wood & $\begin{array}{l}0.0766 \\
(0.121)\end{array}$ & $\begin{array}{l}0.0223 \\
(0.131) \\
\end{array}$ \\
\hline Other & $\begin{array}{c}0.0823 \\
(0.0814) \\
\end{array}$ & $\begin{array}{l}-0.234^{* *} \\
(0.112)\end{array}$ \\
\hline \multicolumn{3}{|l|}{ cut1 } \\
\hline Constant & $\begin{array}{c}-2.491^{* * *} \\
(0.125)\end{array}$ & $\begin{array}{c}-2.466^{* * *} \\
(0.131)\end{array}$ \\
\hline \multicolumn{3}{|l|}{ cut2 } \\
\hline Constant & $\begin{array}{c}-1.231^{* * *} \\
(0.116)\end{array}$ & $\begin{array}{c}-1.200^{\star \star *} \\
(0.122)\end{array}$ \\
\hline \multicolumn{3}{|l|}{ cut3 } \\
\hline Constant & $\begin{array}{c}0.737^{\star * *} \\
(0.116)\end{array}$ & $\begin{array}{l}0.788^{* * *} \\
(0.122)\end{array}$ \\
\hline \multicolumn{3}{|l|}{ cut4 } \\
\hline Constant & $\begin{array}{c}2.098^{* * *} \\
(0.119)\end{array}$ & $\begin{array}{c}2.191^{* * *} \\
(0.126)\end{array}$ \\
\hline \multicolumn{3}{|l|}{ cut5 } \\
\hline Constant & $\begin{array}{c}3.008^{* * *} \\
(0.125)\end{array}$ & $\begin{array}{c}3.055^{\star * *} \\
(0.134)\end{array}$ \\
\hline $\begin{array}{l}\text { McFadden Pseudo R2 } \\
\% \text { of correct prediction }\end{array}$ & $\begin{array}{l}0.132 \\
62.7 \%\end{array}$ & $\begin{array}{l}0.112 \\
64.2 \%\end{array}$ \\
\hline $\begin{array}{l}\text { Overall significant test: } \\
\text { p-value }\end{array}$ & 0.000 & 0.000 \\
\hline Observations & 9,485 & 8,819 \\
\hline \multicolumn{3}{|c|}{$\begin{array}{l}\text { Likelihood ratio test of rho21 }=\text { rho31 }=\text { rho32 }=0: \\
\text { chi2 } 2(3)=51.1687 \text { Prob }>\text { chi2 }=0.0000\end{array}$} \\
\hline
\end{tabular}

Note: Robust standard errors in parentheses ${ }^{* * *} p<0.01,{ }^{* *} p<0.05,{ }^{*} p<0.1$ 